Historic, Archive Document

Do not assume content reflects current scientific knowledge, policies, or practices. 


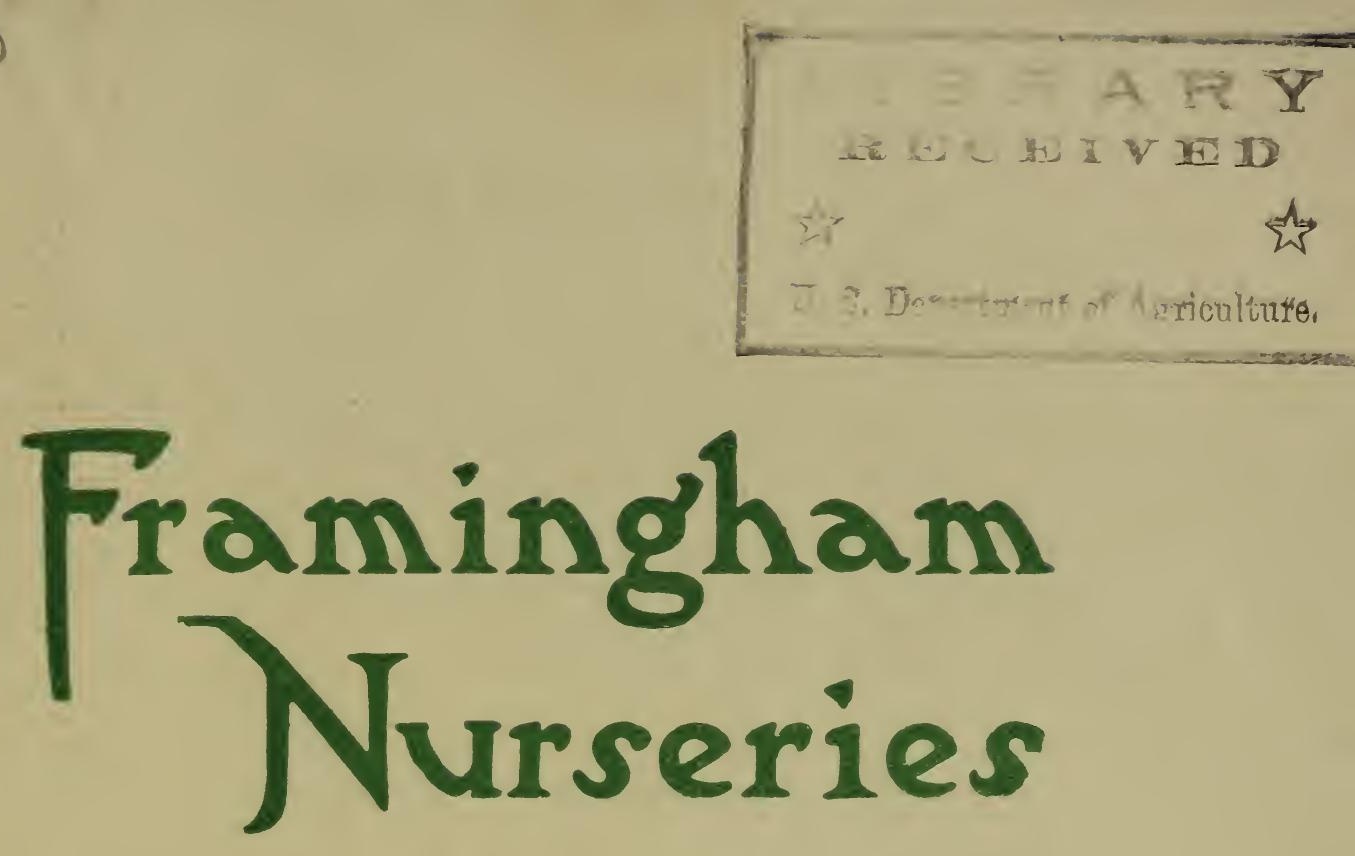

FALL

1921 
Evergreen Trees ............................ 3

Evergreen Shrubs .............................. 17

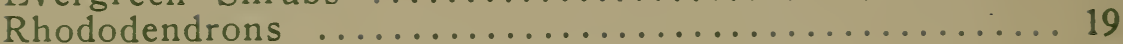

Deciduous Trees ............................. 21

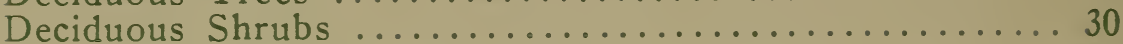

Vines and Climbers ............................ 46

Roses .............................. 48

Fruit Trees .............................. 50

Small Fruits ............................. 51

Index to Botanical Names ...................... 51

Index to Common Names ........................ 53

Our Location ............................... 55

\section{THE PLANTING SEASON}

Evergreen Trees and Shrubs are successfully transplanted in August, September and October. Deciduous Trees, Shrubs and Vines may be planted as soon as the leaves start dropping-usually in late September-until the ground freezes-generally in early December.

\section{SHIPPING DIRECTIONS}

Parties ordering are requested to state explicitly the mode of conveyance by which they desire their stock forwarded. When no route is designated, we exercise our judgment; but in no case do we assume any responsibility after packages are shipped, unless for our own mistakes. When losses occur by detention, claims should at once be made on the transportation company.

Certificate of Inspection Accompanies every Shipment.

\section{CONDITIONS OF SALE}

1. The articles on the following list will be furnished at the annexed prices only when the quantity specified shall be taken. FORTY of the same variety and size will be furnished at the hundred rate; and FIVE at the ten rate. The prices stated are for stock of our selection. Purchasers desiring to select specimen stock must expect to pay higher prices.

2. We give'no warranty, expressed or implied, as to quality, description, productiveness, or any other matter of any nursery stock that we sell. No complaints as to shortages, quality of stock, or faulty packing will be considered unless made within five days after receipt of stock.

3. The prices annexed are for the stock F. O. B. our nurseries. They do not include the packing boxes or bales. We charge for the actual cost of the boxes or the material used in baling except on orders paid in full in advance. We make no charge for the delivery of shipments to the freight or express stations.

4. This price list cancels all previous lists. We reserve the right to change the annexed prices at any time without notice.

5. Our terms are net cash, unless by special arrangement. We will ship by Express C. O. D. when desired, with charges for collection added to the bill-provided 50 per cent of the amount of the order accompanies the order as a guarantee. All charge accounts thirty days overdue will accrue interest at the rate of six per cent per year beginning with the thirtyfirst day.

\section{FRAMINGHAM NURSERIES}

RICHARD M. WYMAN, Proprietor

September, 1921.

Framingham, Mass.

Long Distance Telephone, Framingham 331.

Telegraphic Address, Framingham, Mass.

Cable Address, Fram. Boston. 


\section{HARDY EVERGREEN TREES}

The stock of evergreens herein listed has been very carefully grown.

Not only have the tops been pruned so as to make them into fine specimens, but the ROOTS also have been PRUNED and the plants themselves have beenTRANSPLANTED several times. This results in a mass of fibrous roots which is the deciding factor in the successful planting of evergreens. For this reason our evergreens should not be confused with quickly and cheaply grown, non-pruned and non-transplanted stock. A trial of our evergreens will easily convince.

We always Ball and Burlap our evergreens at No Additional Cost.

ABIES arizonica

5 to $6 \mathrm{ft}$.

arizonica glauca

balsamea

$$
4 \text { to }
$$

5 to $6 \mathrm{ft}$.

6 to $7 \mathrm{ft} . \ldots \ldots \ldots \ldots \ldots \ldots \ldots$

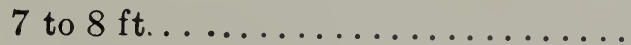

8 to $9 \mathrm{ft}$

9 to $10 \mathrm{ft}$

10 to $12 \mathrm{ft}$

bal. hudsonica glauca

12 to 15 in.

brachyphylla

4 to $5 \mathrm{ft}$.

5 to $6 \mathrm{ft}$ concolor

6

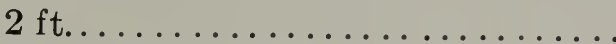

$21 / 2 \mathrm{ft} . \ldots \ldots \ldots \ldots \ldots \ldots \ldots$

$3 \mathrm{ft} . \ldots \ldots \ldots \ldots \ldots \ldots \ldots \ldots$

$4 \mathrm{ft} . \ldots \ldots \ldots \ldots \ldots \ldots \ldots \ldots$

$5 \mathrm{ft}$

$6 \mathrm{ft} . \ldots \ldots \ldots \ldots \ldots \ldots \ldots \ldots$

$7 \mathrm{ft} . \ldots \ldots \ldots \ldots \ldots \ldots \ldots \ldots$

$8 \mathrm{ft} . \ldots \ldots \ldots \ldots \ldots \ldots \ldots \ldots \ldots \ldots$

9 to $15 \mathrm{ft}$
Each Per 10 Per 100 Arizona Fir

1000

1000

\section{Blue Arizona Fir}

\section{Balsam Fir}

300

400

500

600

800

1000

Hudson Bay Fir

400

Short-leaved Fir

500

600

750

\section{Silver Fir}

$350 \quad 3200 \quad 30000$

$500 \quad 4500 \quad 40000$

$\begin{array}{lllll}600 & 5500 & 50000\end{array}$

$800 \quad 7500 \quad 65000$

$\begin{array}{llll}10 & 00 \quad 9000\end{array}$

1250

1500

1800

5000

frazeri

5 to $6 \mathrm{ft}$

Frazer Fir

6 to $7 \mathrm{ft}$

500

frazeri prostrata

A New and Distinctive Dwarf Plant

Dwarf Frazer Fir

2 to $21 / 2 \mathrm{ft}$. spread............. 1000

$21 / 2$ to $3 \mathrm{ft}$. spread............ 1500

3 to $4 \mathrm{ft}$. spread............... 2000

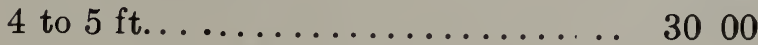


ABIES-continued

veitchii

4 to $5 \mathrm{ft} \ldots \ldots \ldots \ldots \ldots \ldots \ldots \ldots \ldots$

5 to $6 \mathrm{ft} \ldots \ldots \ldots \ldots \ldots \ldots \ldots \ldots$

8 to $9 \mathrm{ft} \ldots \ldots \ldots \ldots \ldots \ldots \ldots \ldots$

9 to $10 \mathrm{ft} . \ldots \ldots \ldots \ldots \ldots \ldots \ldots \ldots . \ldots \ldots$

10 to $12 \mathrm{ft} . \ldots \ldots \ldots \ldots \ldots \ldots \ldots \ldots$

12 to $14 \mathrm{ft} . \ldots \ldots \ldots \ldots \ldots \ldots \ldots \ldots$

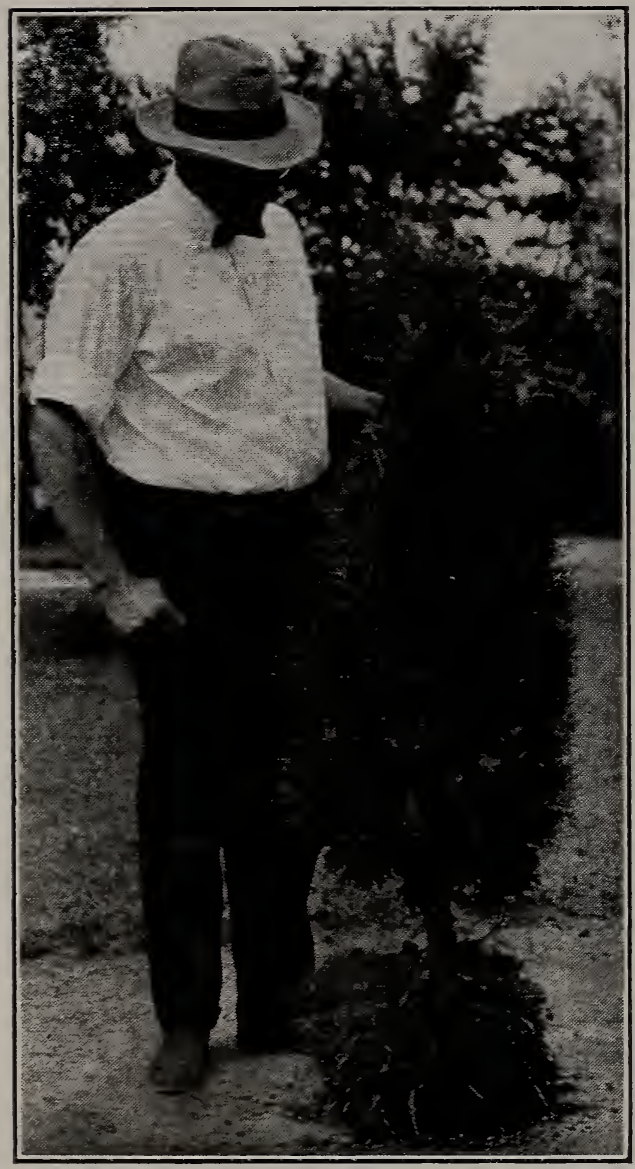

The result of transplanting and rootpruning - a compact mass of fibrous roots to.which the soil adheres.

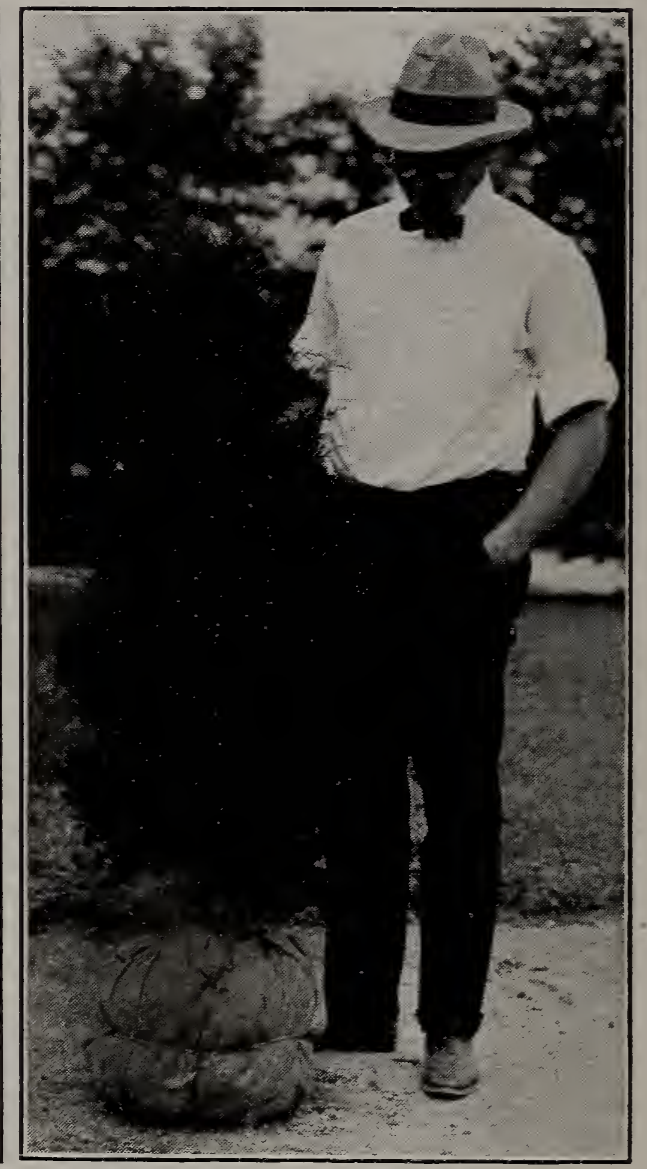

The ball of earth securely tied in burlap. No evergreen is complete without this treatment-for which we make no charge.

\section{JUNIPERUS chinensis}

\section{Chinese Juniper}

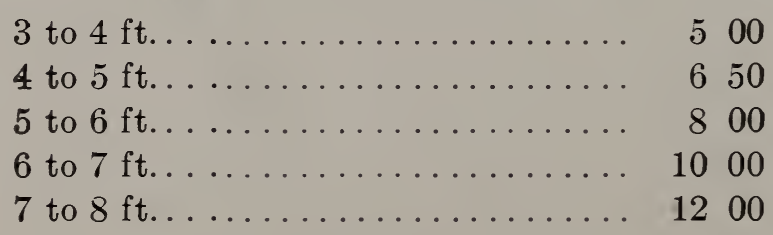




\section{JUNIPERUS-continued}

chin. pfitzeriana

$21 / 2$ to $3 \mathrm{ft}$. spread

3 to $4 \mathrm{ft}$. spread.

4 to $5 \mathrm{ft}$ spread.

communis depressa

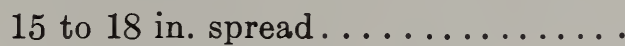

18 to 24 in. spread.

2 to $21 / 2 \mathrm{ft}$. spread

$21 / 2$ to $3 \mathrm{ft}$. spread

3 to $4 \mathrm{ft}$. spread

4 to $5 \mathrm{ft}$. spread

5 to $6 \mathrm{ft}$. spread.

com. dep. aurea

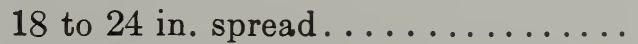

2 to $2 \frac{1}{2} \mathrm{ft}$. spread

com. cracovica

2 to $21 / 2 \mathrm{ft}$.

$21 / 2$ to $3 \mathrm{ft}$

3 to $4 \mathrm{ft}$.

com. hibernica

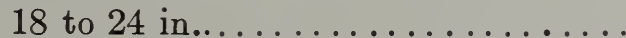

2 to $21 / 2 \mathrm{ft} . \ldots \ldots \ldots \ldots \ldots \ldots . . . . .$.

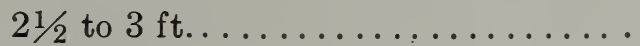

3 to $4 \mathrm{ft}$.

4 to $5 \mathrm{ft}$.

5 to $6 \mathrm{ft}$.

com. oblonga

5 to $6 \mathrm{ft} . \ldots \ldots \ldots \ldots \ldots \ldots . . . . . .1000$

com. suecica

18 to 24 in

2 to $21 / 2 \mathrm{ft} . \ldots \ldots \ldots \ldots \ldots \ldots \ldots$

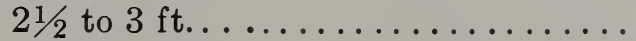

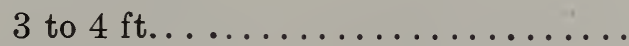
excelsa stricta

12 to 15 in.

15 to 18 in.

18 to 24 in.

3 to $4 \mathrm{ft}$. . .

4 to $5 \mathrm{ft}$.

5 to $6 \mathrm{ft}$.

japonica
Each Per $10 \quad$ Per 100

Pfitzer's Juniper

$\begin{array}{llll}600 & 5500\end{array}$

$\begin{array}{llll}9 & 00 & 8500\end{array}$

$\begin{array}{llll}12 & 00 & 110 & 00\end{array}$

Common Spreading Juniper

$\begin{array}{llllll}1 & 60 & 14 & 00 & 120 & 00\end{array}$

$\begin{array}{llllll}2 & 00 & 18 & 00 & 160 & 00\end{array}$

$\begin{array}{llllll}250 & 2200 & 200 & 00\end{array}$

$350 \quad 3000$

550

800

1000

Golden Common Juniper $300 \quad 2800$

400

\section{Polish Juniper}

$240 \quad 2100$

$\begin{array}{llll}3 & 00 & 27 & 00\end{array}$

$\begin{array}{llll}4 & 00 & 36 & 00\end{array}$

Irish Juniper

$\begin{array}{llllll}140 & 12 & 00 & 100 & 00\end{array}$

$160 \quad 1400$

$\begin{array}{llll}2 & 00 & 18 & 00\end{array}$

$\begin{array}{llll}3 & 00 & 27 & 00\end{array}$

450

$\begin{array}{ll}6 & 00\end{array}$

Caucasian Juniper

Swedish Juniper

$\begin{array}{llllll}1 & 40 & 12 & 00 & 100 & 00\end{array}$

$\begin{array}{llllll}1 & 60 & 14 & 00 & 120 & 00\end{array}$

$\begin{array}{lllllll}2 & 00 & 18 & 00 & 160 & 00\end{array}$

$\begin{array}{llllll}3 & 00 & 27 & 00 & 240 & 00\end{array}$

Greek Juniper

$200 \quad 1800$

$250 \quad 2250$

$350 \quad 3200$

600

800

1200

Japanese Juniper

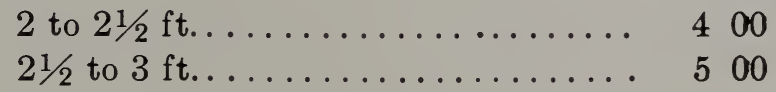

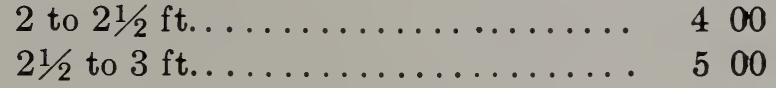


JUNIPERUS-continued

jap. aurea

2 to $21 / 2 \mathrm{ft} . \ldots \ldots \ldots \ldots \ldots \ldots \ldots$

$21 / 2$ to $3 \mathrm{ft} . \ldots \ldots \ldots \ldots \ldots \ldots \ldots . \ldots \ldots$

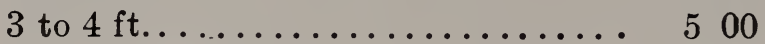

macrocarpa (neaboriensis)

$21 / 2$ to $3 \mathrm{ft} . \ldots \ldots \ldots \ldots \ldots \ldots \ldots$

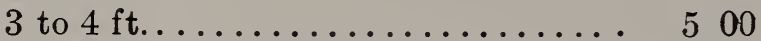

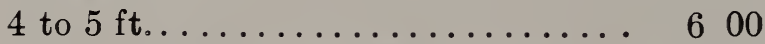

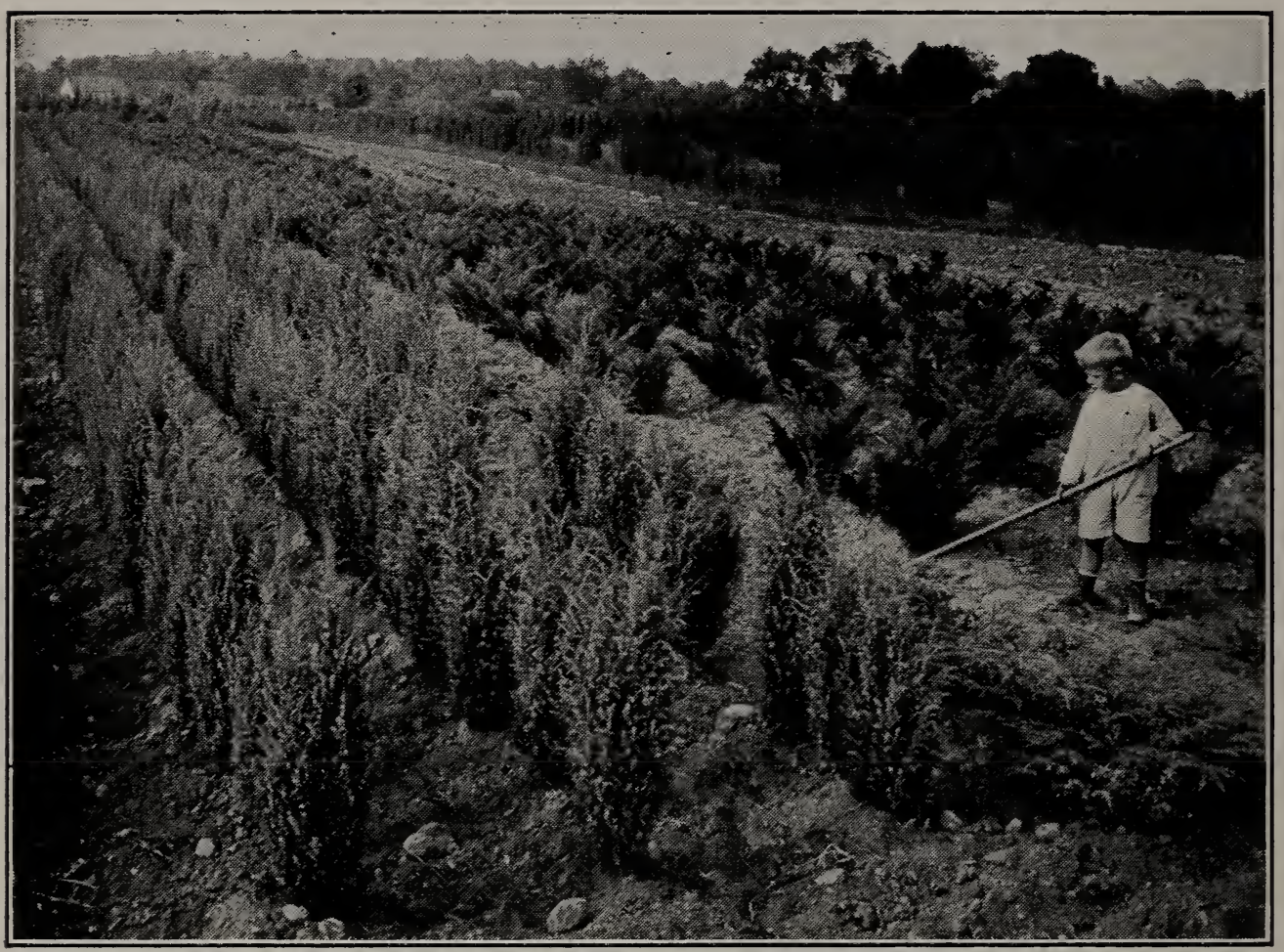

A block of assorted Junipers. Note the interesting shapes to be found in this family of evergreens sabina

12 to 15 in. spread............ 160

15 to 18 in. spread............ 200

18 to 24 in. spread............ 250

2 to $21 / 2 \mathrm{ft}$. spread.............. 300

$21 / 2$ to $3 \mathrm{ft}$. spread............ 450

3 to $4 \mathrm{ft}$. spread.............. 600

4 to $5 \mathrm{ft}$. spread............. 900

virginalis globosa

9 to 12 in. spread............. 300

12 to 15 in. spread........... $400 \quad 3800$

15 to 18 in. spread............ $500 \quad 4500$ 


\section{JUNIPERUS - continued}

virginiana

2 to $3 \mathrm{ft} . \ldots \ldots \ldots \ldots \ldots \ldots$

3 to $4 \mathrm{ft} . \ldots \ldots \ldots \ldots \ldots \ldots \ldots$

4 to $5 \mathrm{ft} . \ldots \ldots \ldots \ldots \ldots \ldots$

5 to $6 \mathrm{ft} \ldots \ldots \ldots \ldots \ldots \ldots \ldots$

6 to $7 \mathrm{ft} . \ldots \ldots \ldots \ldots \ldots \ldots$

7 to $8 \mathrm{ft} . \ldots \ldots \ldots \ldots \ldots \ldots \ldots$

8 to $9 \mathrm{ft} . \ldots \ldots \ldots \ldots \ldots \ldots \ldots \ldots$

9 to $10 \mathrm{ft} . \ldots \ldots \ldots \ldots \ldots \ldots \ldots$

10 to $12 \mathrm{ft} . \ldots \ldots \ldots \ldots \ldots \ldots \ldots$

\section{Each Per 10 Per 100}

Red or Virginia Cedar

$250 \quad 2200 \quad 20000$

$\begin{array}{llllll}300 & 28 & 00 & 26000\end{array}$

$\begin{array}{llllll}4 & 00 & 38 & 00 & 360 & 00\end{array}$

$\begin{array}{llllll}6 & 00 & 55 & 00 & 500 & 00\end{array}$

$\begin{array}{llll}9 & 00 & 8500\end{array}$

$\begin{array}{llll}12 & 00 & 110 & 00\end{array}$

$\begin{array}{llll}18 & 00 & 170 & 00\end{array}$

$\begin{array}{llll}24 & 00 & 230 & 00\end{array}$

$3000 \quad 290 \quad 00$

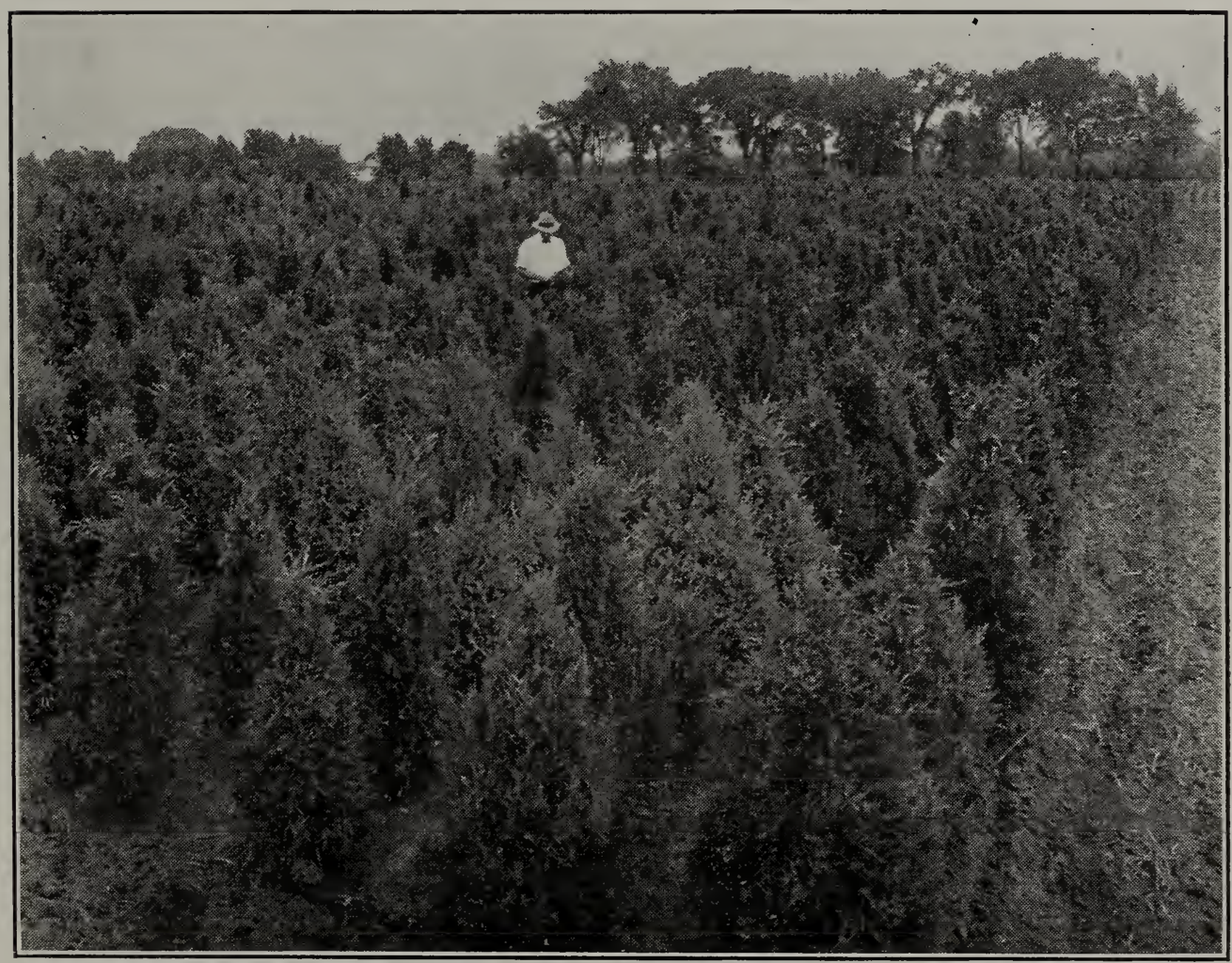

Note the bushiness of these Red Cedars (Juniperus virginiana). This feature, which is difficult to obtain-particularly at the base-is the result of proper soil selection and severe top pruning. It requires more time to grow this grade of tree but you receive the best possible stock.

virg. elegantissima

$21 / 2$ to $3 \mathrm{ft} . \ldots \ldots \ldots \ldots \ldots \ldots$

3 to $4 \mathrm{ft}$.

4 to $5 \mathrm{ft} . \ldots \ldots \ldots \ldots \ldots \ldots \ldots \ldots$

5 to $6 \mathrm{ft} . \ldots \ldots \ldots \ldots \ldots \ldots \ldots \ldots$

6 to $7 \mathrm{ft} \ldots \ldots \ldots \ldots \ldots \ldots \ldots \ldots$

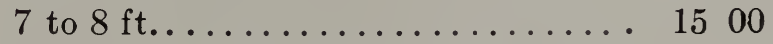

Golden Virginia Cedar

450

600

1500 
JUNIPERUS-continued

virg. glauca

3 to $4 \mathrm{ft} . \ldots \ldots \ldots \ldots \ldots \ldots \ldots . \ldots 60 . \ldots$

4 to $5 \mathrm{ft} . \ldots \ldots \ldots \ldots \ldots \ldots \ldots . \ldots . \ldots . \ldots$

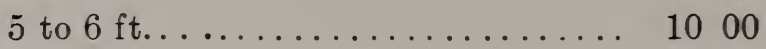

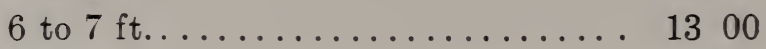

7 to $8 \mathrm{ft} . \ldots \ldots \ldots \ldots \ldots \ldots \ldots \ldots \ldots$

8 to $9 \mathrm{ft} \ldots \ldots \ldots \ldots \ldots \ldots \ldots \ldots . \ldots 2400$

9 to $10 \mathrm{ft} . \ldots \ldots \ldots \ldots \ldots \ldots \ldots \ldots$

virg. schotti

3 to $4 \mathrm{ft}$

4 to $5 \mathrm{ft}$.

5 to $6 \mathrm{ft}$

6 to $7 \mathrm{ft}$.

PICEA alba

18 to 24 in

2 to $3 \mathrm{ft}$.

3 to $4 \mathrm{ft}$.

8 to $9 \mathrm{ft}$.

9 to $10 \mathrm{ft}$.

10 to $12 \mathrm{ft}$.

12 to $14 \mathrm{ft}$

engelmanni

8 to $9 \mathrm{ft}$. specimens.

9 to $10 \mathrm{ft}$. specimens

10 to $12 \mathrm{ft}$. specimens

12 to $18 \mathrm{ft}$. specimens excelsa

3 to $4 \mathrm{ft}$

4 to $5 \mathrm{ft}$.

5 to $6 \mathrm{ft}$.

10 to $12 \mathrm{ft}$

12 to $14 \mathrm{ft}$.

14 to $18 \mathrm{ft}$.

WE OFFER THE THREE FOLLOWING VARIETIES OF

DWARF SPRUCES. THESE ARE VERY RARE PLANT GEMS AND WILL BE GREATLY APPRECIATED BY THE PLANT LOVER.

exc. dumosa

Bushy Dwarf Spruce

2 to $21 / 2 \mathrm{ft} . \ldots \ldots \ldots \ldots \ldots \ldots \ldots \ldots$

$21 / 2$ to $3 \mathrm{ft}$. spread........................ 1800

3 to $4 \mathrm{ft}$. spread............. 2500

exc. gregoryana

$21 / 2$ to $3 \mathrm{ft}$. spread............. 1200

3 to $4 \mathrm{ft} . \ldots \ldots \ldots \ldots \ldots \ldots \ldots \ldots, 1800$

4 to $5 \mathrm{ft} . \ldots \ldots \ldots \ldots \ldots \ldots \ldots \ldots . \ldots \ldots$ 
PICEA-continued

exc. maxwelli

18 in. spread............... 1800

nigra

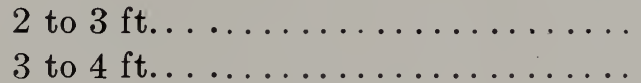

omorica

5 to $6 \mathrm{ft} . \ldots \ldots \ldots \ldots \ldots \ldots \ldots 00$
Each Per 10 Per 100

Maxwell's Dwarf Spruce

Black Spruce

$200 \quad 1800$

$250 \quad 2250$

Serbian Spruce

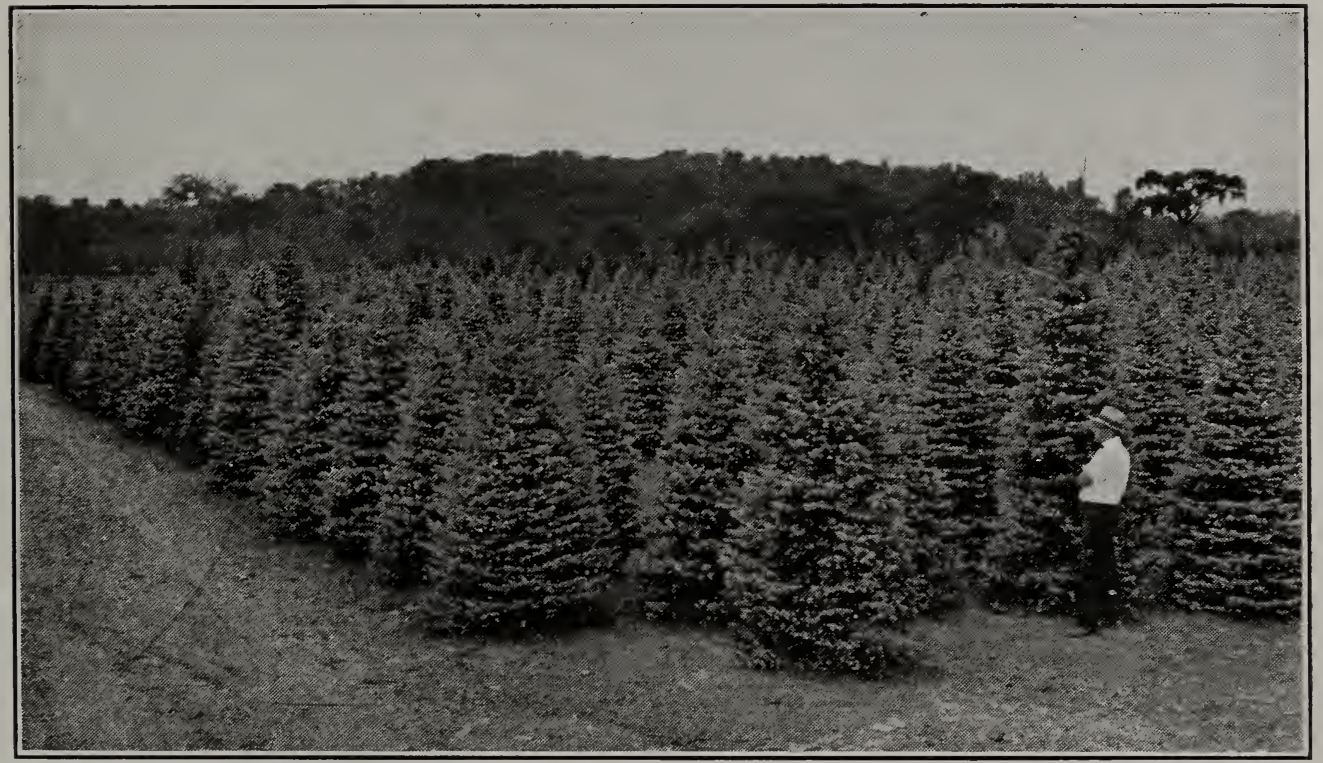

This is a block of Koster Blue Spruce from 7 to 12 feet in height. Each tree a specimen with plenty of roots to assure planting success. Further evidence of the careful attention given to the growing of our stock.

pungens

2 to $3 \mathrm{ft} . \ldots \ldots \ldots \ldots \ldots \ldots \ldots \ldots \ldots \ldots \ldots \ldots \ldots$

Colorado Green Spruce

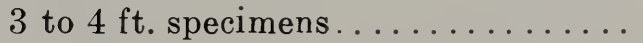

$\begin{array}{llllll}3 & 00 & 28 & 00 & 250 & 00\end{array}$

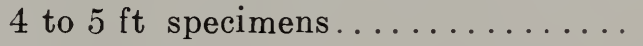

5 to $6 \mathrm{ft}$. specimens............ 800

6 to $7 \mathrm{ft}$. specimens.............. 1000

7 to $8 \mathrm{ft}$ specimens............. 1200

8 to $15 \mathrm{ft}$. specimens........1500 to 3500

pung. glauca

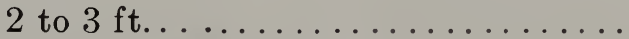

3 to $4 \mathrm{ft}$. specimens..............

4 to $5 \mathrm{ft}$. specimens.............

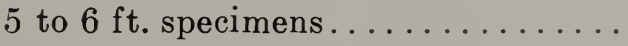

7 to $8 \mathrm{ft}$. specimens.............. 1400

8 to $9 \mathrm{ft}$. specimens............. 1600

9 to $10 \mathrm{ft}$. specimens............ 2000

10 to $16 \mathrm{ft}$. specimens......25 00 to 5000

\section{Colorado Blue Spruce}

$\begin{array}{llllll}5 & 00 & 45 & 00 & 400 & 00\end{array}$

$\begin{array}{llllll}7 & 00 & 60 & 00 & 540 & 00\end{array}$

$\begin{array}{llrl}9 & 00 & 85 & 00\end{array}$

$\begin{array}{llll}11 & 00 & 100 & 00\end{array}$

11000

13000

15000

18000 


\section{PICEA-continued}

6 to $7 \mathrm{ft}$. specimens

7 to $8 \mathrm{ft}$. specimens

8 to $9 \mathrm{ft}$. specimens.............. 2200

9 to $10 \mathrm{ft}$. specimens.

10 to $12 \mathrm{ft}$. specimens.

3000 to 5000

1500 pung. kosteriana

Each Per 10 Per 100

Koster Blue Spruce

$\begin{array}{llll}18 & 00 & 160 & 00\end{array}$

$\begin{array}{llll}22 & 00 & 200 & 00\end{array}$

$2500 \quad 240 \quad 00$

pung. KOSTER COLORED (from seed)

\begin{tabular}{|c|c|}
\hline 2 to $3 \mathrm{ft}$. & 600 \\
\hline 3 to $4 \mathrm{ft}$.. & 800 \\
\hline
\end{tabular}

PINUS austriaca

Austrian Pine

$21 / 2$ to $3 \mathrm{ft}$

$275 \quad 2500$

22500

3 to $4 \mathrm{ft}$. specimens.

400

$38 \quad 00$

35000

4 to $5 \mathrm{ft}$. specimens

500

4800

42500

5 to $6 \mathrm{ft}$. specimens.

700

6500

60000

6 to $7 \mathrm{ft}$. specimens.

850

$80 \quad 00$

70000

7 to $8 \mathrm{ft}$. specimens.

1000

$90 \quad 00$

80000

8 to $9 \mathrm{ft}$ specimens

cembra (five-leaved)

2 to $3 \mathrm{ft}$.

$\begin{array}{llll}12 & 00 & 110 & 00\end{array}$

3 to $4 \mathrm{ft}$.

Swiss Stone Pine

400

500

divaricata or banksiana

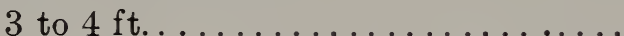

Jack Pine

200

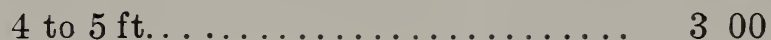

densiflora

Japanese Red Pine

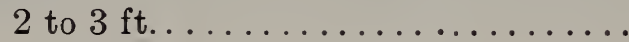

200

1800

15000

3 to $4 \mathrm{ft} . \ldots \ldots \ldots \ldots \ldots \ldots \ldots$

250

2100

18000

4 to $5 \mathrm{ft}$.

300 2500

21000

montana

2 to $21 / 2 \mathrm{ft} . \ldots \ldots \ldots \ldots \ldots \ldots \ldots$

Mountain Pine

$350 \quad 3200$

$450 \quad 4200$

$600 \quad 5500$

900

5 to $6 \mathrm{ft} . \ldots \ldots \ldots \ldots \ldots \ldots \ldots . \ldots 1200$

mont. mughus

Dwarf Mountain Pine

15 to 18 in. spread............. $225 \quad 2000 \quad 18000$

18 to 24 in. spread ............. $300 \quad 2800 \quad 26000$

2 to $21 / 2 \mathrm{ft}$. spread.............. $400 \quad 3800 \quad 36000$

$21 / 2$ to $3 \mathrm{ft}$. spread............. $500 \quad 4800 \quad 42000$

3 to $31 / 2 \mathrm{ft}$. spread.............. $750 \quad 7000 \quad 55000$

$31 / 2$ to $4 \mathrm{ft}$. spread.............. $1000 \quad 9000 \quad 700 \quad 00$

4 to $5 \mathrm{ft}$ spread............... $1250 \quad 11000$

5 to $6 \mathrm{ft}$. spread.............. 1500

monticola (five-leaved)

2 to $21 / 2 \mathrm{ft} . \ldots \ldots \ldots \ldots \ldots \ldots . .300$

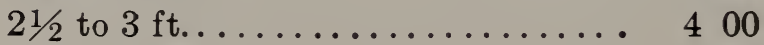

3 to $4 \mathrm{ft} . \ldots \ldots \ldots \ldots \ldots \ldots \ldots . \ldots \ldots$
Mountain White Pine 


\section{PINUS-continued}

resinosa

4 to $5 \mathrm{ft} . \ldots \ldots \ldots \ldots \ldots \ldots \ldots \ldots$

5 to $6 \mathrm{ft} \ldots \ldots \ldots \ldots \ldots \ldots \ldots \ldots$

6 to $7 \mathrm{ft} . \ldots \ldots \ldots \ldots \ldots \ldots \ldots \ldots$

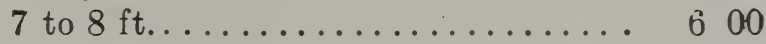

Each Per 10 Per 100

Red or Noruay Pine

$00 \quad 2500 \quad 20000$

$3500 \quad 28000$

$\begin{array}{llll}42 & 00 & 360 & 00\end{array}$

$\begin{array}{llll}50 & 00 \quad 420 & 00\end{array}$

White Pine

strobus

3 to $4 \mathrm{ft} \ldots \ldots \ldots \ldots \ldots \ldots \ldots \ldots . \ldots \ldots$

$2250 \quad 20000$

4 to $5 \mathrm{ft} \ldots \ldots \ldots \ldots \ldots \ldots \ldots \ldots$

$3500 \quad 30000$

5 to $6 \mathrm{ft} . \ldots \ldots \ldots \ldots \ldots \ldots \ldots \ldots \ldots$

$4500 \quad 40000$

6 to $7 \mathrm{ft} . \ldots \ldots \ldots \ldots \ldots \ldots \ldots 60 \ldots$

5500

50000

7 to $8 \mathrm{ft}$.

10 to $12 \mathrm{ft}$

800

7500

12 to $14 \mathrm{ft} . \ldots \ldots \ldots \ldots \ldots \ldots \ldots \ldots$

14 to $18 \mathrm{ft}$.

sylvestris

18 to $24 \mathrm{in}$.

2 to $3 \mathrm{ft}$.

3 to $4 \mathrm{ft}$.

6 to $7 \mathrm{ft}$

7 to $8 \mathrm{ft}$

8 to $9 \mathrm{ft}$.

PSEUDOTSUGA taxifolia

18 to 24 in

2 to $3 \mathrm{ft}$.

3 to $4 \mathrm{ft}$.

4 to $5 \mathrm{ft}$

5 to $6 \mathrm{ft}$

6 to $7 \mathrm{ft}$

7 to $8 \mathrm{ft}$

8 to $10 \mathrm{ft}$.

10 to $12 \mathrm{ft}$.

12 to $14 \mathrm{ft}$

RETINISPORA filifera

18 to 24 in.

2 to $2 \frac{1}{2} \mathrm{ft}$

$21 / 2$ to $3 \mathrm{ft}$.

fil aurea

15 to 18 in. spread

18 , to 24 in. spread

pisifera

2 to $21 / 2 \mathrm{ft}$.

$21 / 2$ to $3 \mathrm{ft}$.

3 to $4 \mathrm{ft}$. .

4 to $5 \mathrm{ft}$.

7 to $11 \mathrm{ft}$.
2500

Scotch Pine

$\begin{array}{lllllll}1 & 50 & & 72 & 00 & 90 & 00 \\ 1 & 75 & & 15 & 00 & & \\ 2 & 25 & & 20 & 00 & & \\ 5 & 00 & & & \\ 7 & 00 & & & \\ 9 & 00 & & & \end{array}$

Douglas Fir

$\begin{array}{llllll}2 & 00 & 18 & 00 & 150 & 00\end{array}$

$\begin{array}{llllll}3 & 00 & 28 & 00 & 240 & 00\end{array}$

$\begin{array}{llllll}4 & 00 & 38 & 00 & 360 & 00\end{array}$

$\begin{array}{llll}500 & 48 & 00\end{array}$

$\begin{array}{llll}7 & 00 & 6500\end{array}$

$\begin{array}{llll}9 & 00 \quad 80 & 00\end{array}$

$\begin{array}{llll}11 & 00 & 1(0 & 00\end{array}$

1400

1600

2000

Thread-branched Cypress

$250 \quad 2200$

$350 \quad 3200$

450

Golden Thread-branched Cypress

500

600

Pea-frited Cypress

$\begin{array}{llll}300 & 27 & 00\end{array}$

$\begin{array}{llll}5 & 00 \quad 4500\end{array}$

600

1200 to 2000 $\begin{array}{llll}4 & 00 & 36 & 00\end{array}$ 


\section{RETINISPORA—continued}

pis. aurea

$21 / 2$ to $3 \mathrm{ft}$.

3 to $4 \mathrm{ft} \ldots \ldots \ldots \ldots \ldots \ldots \ldots \ldots \ldots$

4 to $5 \mathrm{ft} . \ldots \ldots \ldots \ldots \ldots \ldots \ldots \ldots$

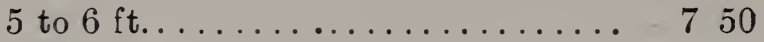

6 to $7 \mathrm{ft} . \ldots \ldots \ldots \ldots \ldots \ldots \ldots$. 10 o

7 to $10 \mathrm{ft} . \ldots \ldots \ldots \ldots \ldots 1200$ to 200 o plumosa

18 to 24 in. sheared specimens......

2 to $2 \frac{1}{2} \mathrm{ft}$ sheared specimens ......

$21 / 2$ to $3 \mathrm{ft}$ sherred spesimon $\ldots .$. .

3 t) $3 \frac{1}{2} \mathrm{ft}$. sheared specimans ......

4 t, 5 it. shəзred spэзi nəns.......

12 to $11 \mathrm{ft}$. she

plum. aurзa

18 tว 24 in. sheared spəcimens......

2 t, $2 \mathrm{r} / 2 \mathrm{ft}$. sheared speciməns......

$21 / 2$ to $3 \mathrm{ft}$. sheared specimens.......

3 to $4 \mathrm{ft}$. sheared specimens........

4 to $5 \mathrm{ft}$. sheared specimens.......

5 to $6 \mathrm{ft}$. sheared specimens........

6 t $7 \mathrm{ft}$. sheared specimens........

7 to $8 \mathrm{ft}$. sheared specimens........

8 to $9 \mathrm{ft}$. sheared specimens. . . . . . . .

9 to $10 \mathrm{ft}$. sheared specimens.......

10 to $12 \mathrm{ft}$. sheared specimens...... 20 0J

squarrosa veitchii

2 to $21 / 2$ ft................ 350

$2 \mathrm{r} / 2$ to $3 \mathrm{ft} \ldots \ldots \ldots \ldots \ldots \ldots \ldots \ldots$

3 to $4 \mathrm{ft} \ldots \ldots \ldots \ldots \ldots \ldots \ldots \ldots$

4 to $5 \mathrm{ft} . \ldots \ldots \ldots \ldots \ldots \ldots \ldots \ldots \ldots$

5 to $6 \mathrm{ft} . \ldots \ldots \ldots \ldots \ldots \ldots \ldots \ldots$

SCIADOPITYS verticillata

18 to 24 in................. 400

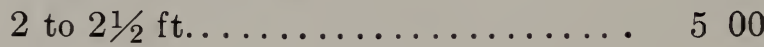

TAXUS canadensis

12 to 15 in. spread. . . . . . . . . . .

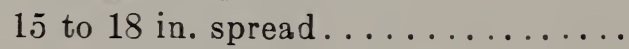

18 to $2 t$ in. spread. . . . . . . . . .

2 to $21 / 2$ ft. spread............ 30

$21 / 2$ to $3 \mathrm{ft}$. spread............ 40 o

cuspidata capitata

18 to 21 in

2 t) $2 \frac{1}{2} \mathrm{ft}$

$2 \mathrm{x} / 2$ to $3 \mathrm{ft} . \ldots \ldots \ldots \ldots \ldots \ldots$

3 to $31 / 2 \mathrm{ft}$.

3003

800

303
Plumed Cypress

4500

5500

7000
$250 \quad 2 \pm 00$

Golden Plumed Cypress

$250 \quad 2100$

2800

$\begin{array}{lll}00 & 3500\end{array}$

4500

$\begin{array}{llll}9 & 00 & 80 & 00\end{array}$

$\begin{array}{llll}10 & 00 & 90 & 00\end{array}$

$\begin{array}{llll}2 & 03 & 110 & 00\end{array}$

0) 14000

Gray $C$ ypress

$50 \quad 3200$

4200

$\begin{array}{lll}65 & 03\end{array}$

9503

Umbrella Pine

American $Y e w$

$\begin{array}{llllll}140 & 12 & 00 & 100 & 00\end{array}$

$\begin{array}{llllll}175 & 15 & 0 J & 130 & 00\end{array}$

$250 \quad 2250$

Upright Japanese Yew

$350 \quad 3000$

$450 \quad 4000$

$\begin{array}{llll}6 & 00 & 55 & 00\end{array}$

$750 \quad 7000$ 
TAXUS-continued cuspidata---spreading form

12 to 15 in. spread.............. $250 \quad 2200$

15 to 18 in. spread............. $320 \quad 3000$

18 to 24 in. spread............ $450 \quad 4200$

2 to $2 \frac{1}{2} \mathrm{ft}$. spread............. $700 \quad 6500$

We have a limited quantity of very fine large specimenis.

Prices quoted upon request.

cusp. brevifolia---upright compact form Upright Dwarf Japanese Yew

9 to 12 in.................... $300 \quad 2700$

12 to 15 in................. $400 \quad 3600$

15 to 18 in .................. 500

cusp. brevifolia---spreading form Spreading Dwarf Japanese Yew

9 to 12 in................... $250 \quad 2250$

12 to 15 in................... $300 \quad 2800$

15 to 18 in............... $400 \quad 3800$

18 to 20 in................ $600 \quad 5700$

THESE PLANTS ARE PARTICULARLY DENSE AND

COMPACT FOR THIS TYPE OF PLANT. THEY ARE

EXCEPTIONALLY FINE SPECIMENS. WE ALSO

HAVE A FEW VERY FINE LARGER SPECIMENS;

PRICES WILL BE QUOTED UPON REQUEST. repandens

12 to 15 in. spread............. $250 \quad 2250$

15 to 18 in. spread.............. 325 sieboldi

$2 \mathrm{ft} \ldots \ldots \ldots \ldots \ldots \ldots \ldots \ldots \ldots$. 800

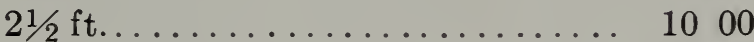

$3 \mathrm{ft} \ldots \ldots \ldots \ldots \ldots \ldots \ldots \ldots \ldots$

THIS IS PERHAPS THE FINEST TYPE OF THE LARGER-GROWING YEWS. THE HABIT IS VARIOUS, RANGING FROM NEARLY OR QUITE PYRAMIDAL, TO SPREADING AND GLOBOSE. THE NEEDLES ARE PARTICULARLY LARGE AND STRONG. THE COLOR IS VERY FINE. A NEW SORT WHICH IS MEETING WITH GREAT POPULARITY.

THUYA occidentalis

American Arborvitae

\begin{tabular}{|c|c|c|c|}
\hline $2 \mathrm{ft}$. & 160 & 1400 & 12000 \\
\hline $3 \mathrm{ft}$. & 200 & $17 \quad 50$ & 15000 \\
\hline $4 \mathrm{ft}$. . & 300 & 2800 & $250 \quad 00$ \\
\hline $5 \mathrm{ft} .$. & 500 & 4500 & 40000 \\
\hline $6 \mathrm{ft.}$. & 700 & 6000 & \\
\hline $7 \mathrm{ft.}$. & 900 & & \\
\hline ft. . & 1100 & & \\
\hline ft. . & 1300 & & \\
\hline ft. & 1500 & & \\
\hline ft. & 2000 & & \\
\hline
\end{tabular}

NOTE: We do not advise transplanting this species in the Fall. All of its varieties, as listed below, DO transplant successfully in the fall, unless otherwise noted. 
THUYA-continued occ. aurea

$$
\begin{aligned}
& 2 \text { to } 3 \mathrm{ft} . \ldots \ldots \ldots \ldots \ldots \ldots \ldots \ldots 180 \quad 1600
\end{aligned}
$$

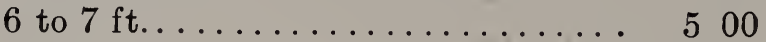

$$
\begin{aligned}
& 10 \text { to } 12 \mathrm{ft} \ldots \ldots \ldots \ldots \ldots \ldots \ldots \ldots
\end{aligned}
$$

occ. columbia

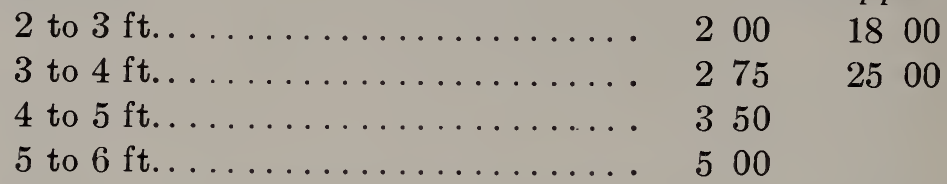

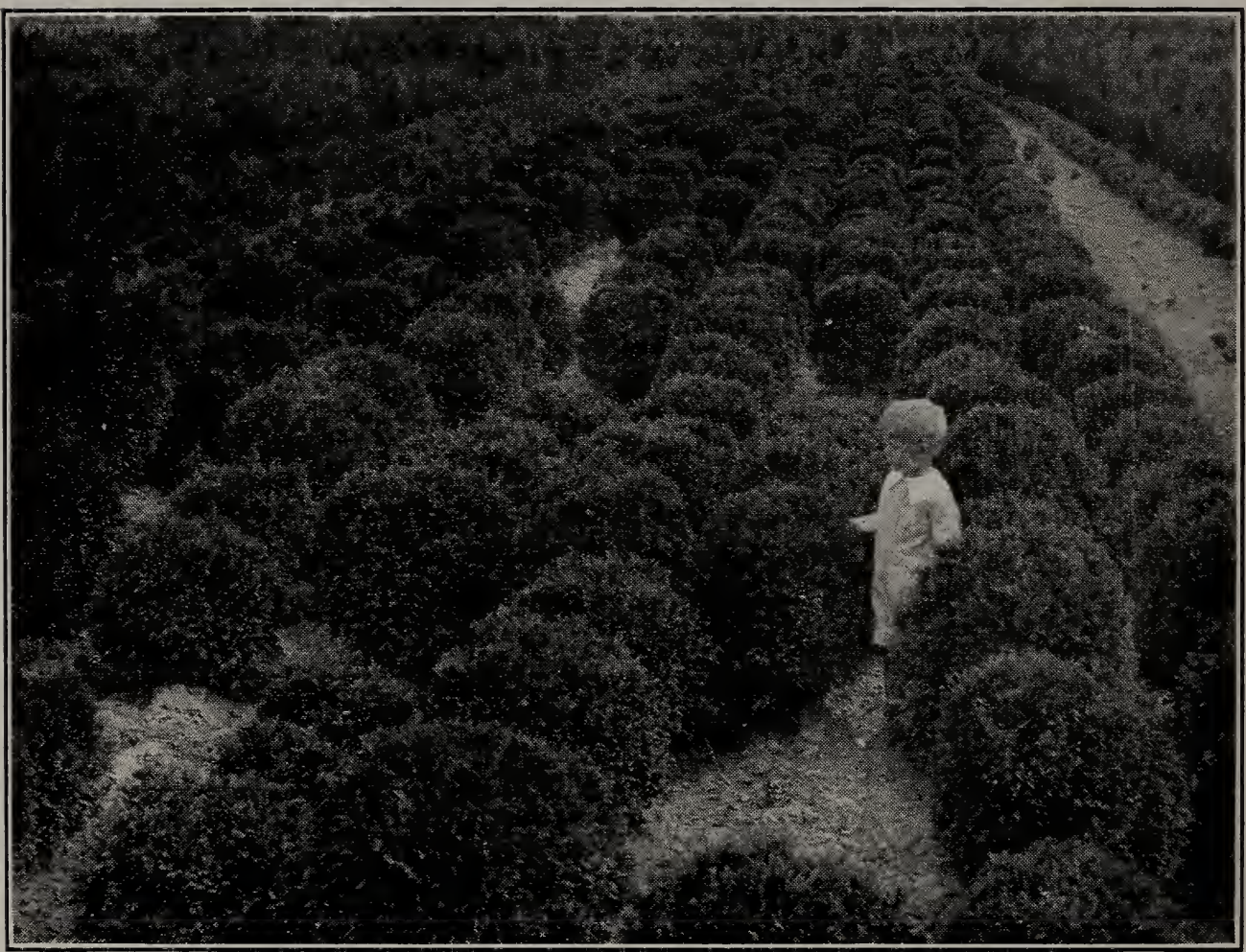

Can you imagine a better material for a low rounding evergreen hedge than these Globe Arborvitae?

occ. cristata

2 to $21 / 2 \mathrm{ft}$.

occ. dolglasi nana

9 to 12 in. spread............. occ. dumosa

18 to 24 in

2 to $21 / 2 \mathrm{ft}$

$21 / 2 \mathrm{t}$, $3 \mathrm{ft}$.

occ. ellwangeriana

2 to $3 \mathrm{ft}$.
Crested Arborvitae

350

Little Gem Arborvitae

300

Bushy Arborvitae

$\begin{array}{llll}3 & 00 & 27 & 00\end{array}$

$\begin{array}{llll}4 & 00 & 36 & 00\end{array}$

$\begin{array}{llll}5 & 00 & 4500\end{array}$

Ellu'anger's Arborvitae 350 
THUYA-continued

occ. globosa

9 to 12 in

12 to 15 in

15 to 18 in

18 to 24 in

2 to $21 / 2$

$21 / 2$ to $3 \mathrm{ft}$

occ. pyramidalis

$3 \mathrm{ft}$.

$31 / 2 \mathrm{ft} . \ldots \ldots \ldots \ldots \ldots \ldots \ldots \ldots$

$4 \mathrm{ft}$.

$41 / 2 \mathrm{ft}$.

$5 \mathrm{ft}$.

$6 \mathrm{ft}$

$7 \mathrm{ft}$.

occ. rosenthali

15 to 18 in

18 to 24 in

2 to $2 \frac{1}{2} \mathrm{ft}$.

occ. siberica

18 to $24 \mathrm{in}$.

2 to $21 / 2 \mathrm{ft}$

$21 / 2$ to $3 \mathrm{ft}$.

3 to $4 \mathrm{ft}$.

4 to 5 it.

occ. spiralis (douglasi pyramidalis)

2 to $21 / 2 \mathrm{ft}$

$21 / 2$ to $3 \mathrm{ft}$

3 to $4 \mathrm{ft}$.

4 to $5 \mathrm{ft}$.

5 to $6 \mathrm{ft}$.

6 to $7 \mathrm{ft}$.

occ. umbraculifera

18 to 24 in. spread.

2 to $21 / 2 \mathrm{ft}$. spread

$21 / 2$ to $3 \mathrm{ft}$. spread

3 to $31 / 2 \mathrm{ft}$. spread

occ. vervaeneana

2 to $21 / 2 \mathrm{ft}$.

$21 / 2$ to $3 \mathrm{ft}$.

3 to $4 \mathrm{ft}$.

4 to $5 \mathrm{ft}$.

5 to $6 \mathrm{ft}$.

6 to $8 \mathrm{ft}$

occ. wagneri

2 to $21 / 2 \mathrm{ft}$.

$21 / 2$ to $3 \mathrm{ft}$

orientalis

4 to $5 \mathrm{ft}$.

5 to $6 \mathrm{ft}$

6 to $7 \mathrm{ft}$.
Each Per 10 Per 100

Globe Arborvitae

$140 \quad 1200$

$175 \quad 1500$

$225 \quad 2000$

$\begin{array}{llll}3 & 00 & 27 & 50\end{array}$

$\begin{array}{llll}4 & 00 & 40 & 00\end{array}$

$\begin{array}{llll}600 & 5500\end{array}$

Pyramidal Arborvitae

$\begin{array}{llllll}3 & 00 & 27 & 00 & 250 & 00\end{array}$

$\begin{array}{llllll}4 & 00 & 36 & 00 & 320 & 00\end{array}$

$\begin{array}{llllll}5 & 00 & 45 & 00 & 400 & 00\end{array}$

$\begin{array}{llllll}6 & 00 & 55 & 00 & 500 & 00\end{array}$

$\begin{array}{llllll}700 & 6500 & 600 & 00\end{array}$

$\begin{array}{llll}10 & 00 & 90 & 00\end{array}$

1500

Rosenthal's Arborvitae

$200 \quad 1800$

$250 \quad 2250$

300

Siberian Arborvitae

$250 \quad 2200$

$\begin{array}{llllll}3 & 00 & 27 & 00 & 250 & 00\end{array}$

$\begin{array}{llll}375 & 3500 & 32000\end{array}$

$\begin{array}{lllll}500 & 4500 & 400 & 00\end{array}$

$\begin{array}{llllll}6 & 50 & 60 & 00 & 550 & 00\end{array}$

Spire-like Arborvitae

250

325

400

600

800

1000

Depressed Glohe Arborvitae

$\begin{array}{llll}300 & 27 & 50\end{array}$

$450 \quad 40 \quad 00$

$\begin{array}{llll}6 & 00 & 55 & 00\end{array}$

800

Vervaen's Arborvitae

$250 \quad 2200$

$\begin{array}{llll}3 & 00 & 27 & 00\end{array}$

400

500

700

900

Wagner's Arborvitae

$250 \quad 2250$

$350 \quad 3200$

Chinese Arborvilae

$500 \quad 4600$

$\begin{array}{llll}700 & 6500\end{array}$ 


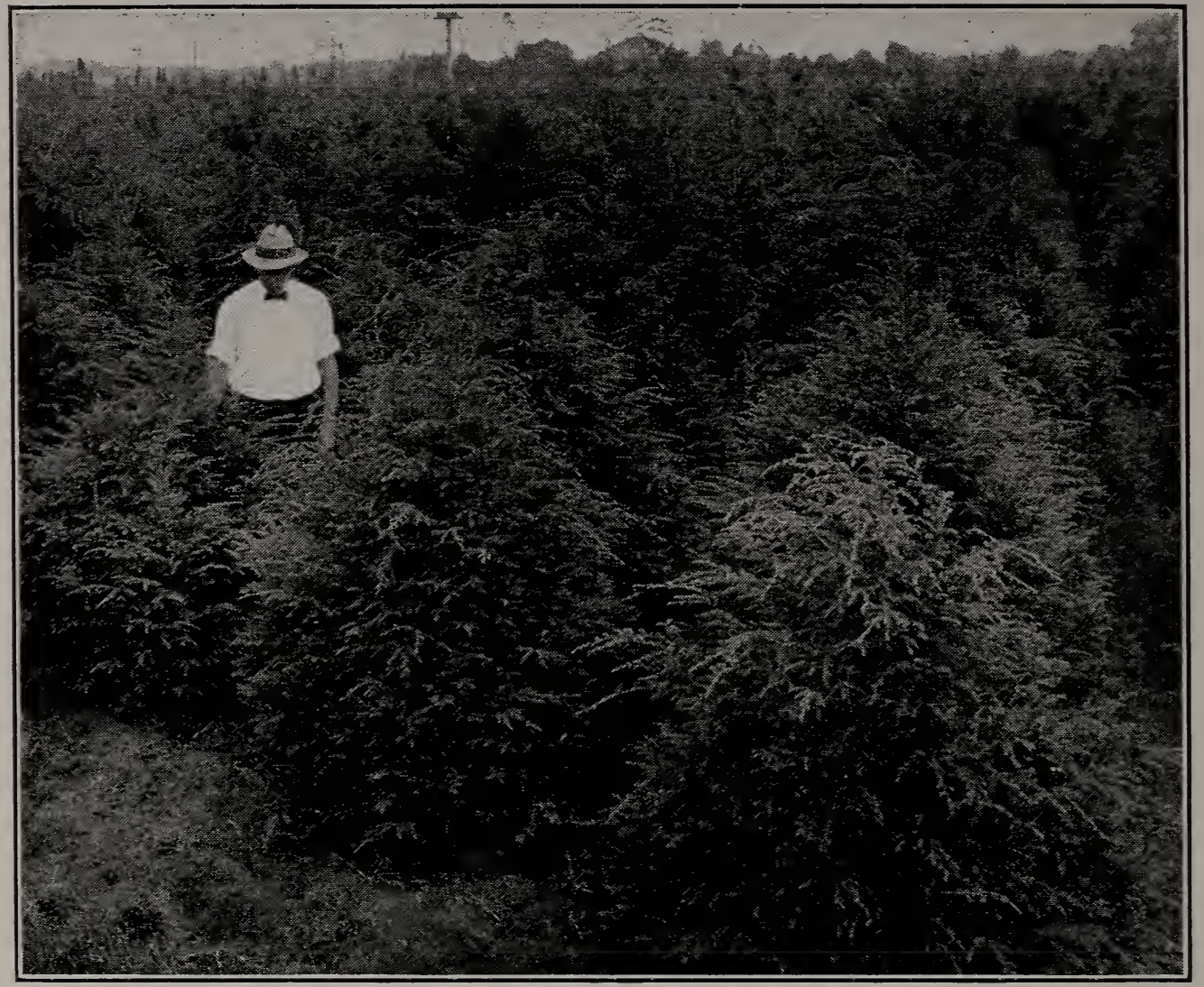

Hemlocks (Tsuga canadensis) of medium and large sizes. Good for a hedge, a screen, a windbreak or for specimen planting-and the roots are as good as the tops.

\section{TSUGA canadensis}

2 to $21 / 2 \mathrm{ft} . \ldots \ldots \ldots \ldots \ldots \ldots \ldots$. . . . . . .

$21 / 2$ to $3 \mathrm{ft} . \ldots \ldots \ldots \ldots \ldots \ldots$.

3 to $31 / 2 \mathrm{ft} . \ldots \ldots \ldots \ldots \ldots \ldots \ldots$

$31 / 2$ to $4 \mathrm{ft} . \ldots \ldots \ldots \ldots \ldots \ldots \ldots$.

$31 / 2$ to $4 \mathrm{ft}$. extra broad............

4 to $5 \mathrm{ft} . \ldots \ldots \ldots \ldots \ldots \ldots \ldots \ldots$.

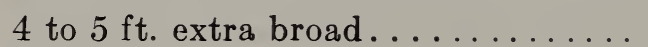

5 to $6 \mathrm{ft} . \ldots \ldots \ldots \ldots \ldots \ldots \ldots$

5 to $6 \mathrm{ft}$. extra broad..............

6 to $7 \mathrm{ft} . \ldots \ldots \ldots \ldots \ldots \ldots \ldots$

7 to $8 \mathrm{ft} . \ldots \ldots \ldots \ldots \ldots \ldots \ldots \ldots$

8 to $9 \mathrm{ft} \ldots \ldots \ldots \ldots \ldots \ldots \ldots$

9 to $10 \mathrm{ft}$.

diversifolia

18 to 24 in

microphylla

$21 / 2$ to $s \mathrm{ft} . . \ldots \ldots \ldots \ldots \ldots \ldots$

3 to $4 \mathrm{ft} \ldots \ldots \ldots \ldots \ldots \ldots \ldots \ldots \ldots$
Each Per 10 Per 100 American Hemluck

$\begin{array}{llllll}2 & 75 & 25 & 00 & 220 & 00\end{array}$

$\begin{array}{llllll}3 & 75 & 35 & 00 & 330 & 00\end{array}$

$450 \quad 4250 \quad 400 \quad 00$

$\begin{array}{llllll}5 & 50 & 52 & 50 & 500 & 00\end{array}$

$\begin{array}{llllll}7 & 00 & 65 & 00 & 600 & 00\end{array}$

$\begin{array}{llllll}7 & 00 & 65 & 00 & 600 & 00\end{array}$

$\begin{array}{llllll}9 & 00 & 85 & 00 & 800 & 00\end{array}$

$\begin{array}{llllll}9 & 00 & 85 & 00 & 800 & 00\end{array}$

$\begin{array}{llllll}11 & 00 & 100 & 00 & 900 & 00\end{array}$

$\begin{array}{llllll}11 & 00 & 100 & 00 & 900 & 00\end{array}$

$\begin{array}{llllll}14 & 00 & 130 & 00 & 1200 & 00\end{array}$

$\begin{array}{lllllll}18 & 00 & 170 & 00 & 1500 & 00\end{array}$

$2000 \quad 19000$

Red-twigged Hemlock

300

Dwarf Pyramidal Hemlock

1000 


\section{EVERGREEN SHRUBS}

Each Per 10 Per 100

ANDROMEDA - See PIERIS

ARCTOSTAPHYLOS uva-ursi

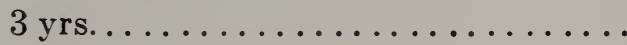

BERBERIS ilicifolia-See page 25

BUXUS arborescens

pyramids

Bearberry

$\begin{array}{llll}60 & 500 & 40 & 00\end{array}$

Holly-leaved Barberry

Boxwood

Pyramidal Box

$21 / 2 \mathrm{ft} . \ldots \ldots \ldots \ldots \ldots \ldots \ldots \ldots .6 \ldots$

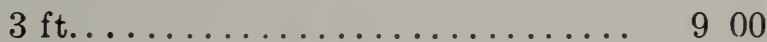

$31 / 2 \mathrm{ft} \ldots \ldots \ldots \ldots \ldots \ldots \ldots \ldots . \ldots \ldots$

CHAMAEDAPHNE calyculata

Leather Leaf

15 to 18 in.................. $100 \quad 900$

COTONEASTER See WILSON'S CHINESE COTONEASTERS Page 27

DAPHNE cneorum

6 to 8 in

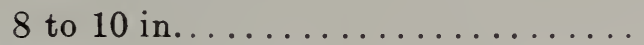

10 to 12 in

EUONYMUS radicans

3 yrs. rad. acutis

2 yrs. .

rad. carrieri

$$
2
$$

rad. minima (kewensis)

3 yrs. . rad. variegata

2 yrs. . .

3 yrs.

rad. vegeta

2 yrs.

3 yrs.

Broad-leaved Garland Flower

\begin{tabular}{|c|c|c|}
\hline 75 & 600 & 5000 \\
\hline 10 & 800 & 7000 \\
\hline 12 & 1000 & 9000 \\
\hline
\end{tabular}

Evergreen Bittersweet

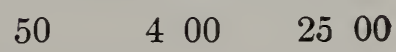

Sharp-leaved Evergreen Bittersweet

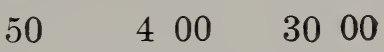
Carrier's Evergreen Bittersweet $\begin{array}{lllll}40 & 300 & 20 & 00\end{array}$ 50
400 3000

Small-leaved Evergreen Bittersweet $\begin{array}{llll}60 & 500 & 40 & 00\end{array}$

Variegated Evergreen Bittersweet $\begin{array}{lllll}40 & 300 & 20 & 00\end{array}$

$\begin{array}{lllll}50 & 400 & 30 & 00\end{array}$




\section{KALMIA angustifolia}

Each Per 10 Per 100

9 to 12 in

Sheep Laurel

12 to 15

100

800

6000

15 to 18 in.

125

1000

7500

18 to 24 in.

150

1350

12000

latifolia

$175 \quad 1600$

15 to 18 in

Mountain Laurel

18 to 24 in.

$200 \quad 1800$

2 to $21 / 2 \mathrm{ft}$. clumps.

$250 \quad 2200$

$21 / 2$ to $3 \mathrm{ft}$. clumps.

$\begin{array}{llll}3 & 00 & 27 & 00\end{array}$

$\begin{array}{llll}400 & 38 & 00\end{array}$

LEUCOTHOE catesbaei

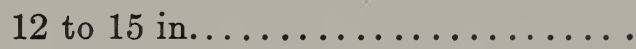

Drooping Andromeda

15 to 18 in.

$120 \quad 1000 \quad 9000$

18 to 24 in

$150 \quad 1400 \quad 12000$

$180 \quad 1600 \quad 14000$

MITCHELLA repens

Partridge Berry

3 yrs.

$60 \quad 500$

PACHYSANDRA terminalis

2 yrs. from pots.............

Japanese Spurge

$200 \quad 1600$

$250 \quad 1800$

PIERIS floribunda

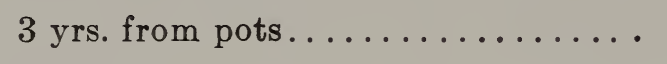

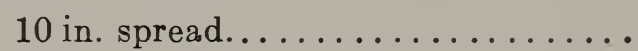

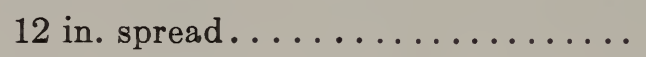

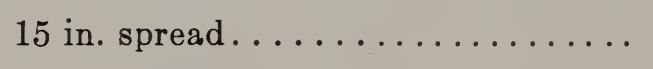

18 in. spread.

VINCA minor

2 yrs. from pots.

$80 \quad 1600$

$240 \quad 2200$

$\begin{array}{llll}350 & 3200\end{array}$

500

Trailing Myrtle

$25 \quad 200$

1500

\section{PLANT FANCIERS}

A careful perusal of this price list will reveal a multitude of plants which will be found to be very beautiful and interesting. Some are new, others are rare, while still others which we have grown for many years are not well known to the general public. All of these sorts are grown with the greatest care and attention. We shall be glad to have you examine them at our nurseries. 


\section{RHODODENDRONS}

Our stock comprises the native varieties, Catawbiense and Maximum as well as the hardiest of the Catawbiense Hybrids. To this list we have recently added Rhododendron Carolinianum, a native sort of great hardiness and beauty, and Rhododendron catawbiense compacta, an interesting hardy, dwarf variety.

RHODODENDRON ALPINE

hirsutum---scarlet

8 to 12 in. spread myrtifolium -red

18 to 24 in.

2 to $21 / 2 \mathrm{ft}$

$21 / 2$ to $3 \mathrm{ft}$ ovatum---pink

15 to 18 in

18 to 24 in................ 400 wilsoni---pink

15 to 18 in

18 to 24 in

2 to $21 / 2 \mathrm{ft}$

Dwarf Hybrid Rhododendrons

$250 \quad 2200$

$300 \quad 2800$

$\begin{array}{llll}400 & 36 & 00\end{array}$

$500 \quad 4500$

$\begin{array}{llll}300 & 27 & 00\end{array}$

3600

$300 \quad 2700$

$\begin{array}{llll}4 & 00 & 36 & 00\end{array}$

500

RHODODENDRON carolinianum - pink

Carolina Rhododendron

15 in. single stemmed at base...... $200 \quad 1800 \quad 16000$

18 in. single stemmed at base...... $250 \quad 2200 \quad 20000$

$2 \mathrm{ft}$. single stemmed at base....... $300 \quad 2700$

catawbiense - deep pink

Catawban Rhododendron

18 in. clumps............... $250 \quad 2250$

$2 \mathrm{ft}$. clumps............... $300 \quad 2750$

$21 / 2 \mathrm{ft}$. clumps............ $400 \quad 3750$

$3 \mathrm{ft}$. clumps............... $500 \quad 4250$

catawb. compacta

Dwarf Catawban Rhododendron

10 to 12 in. clumps............. $180 \quad 1600 \quad 14000$

12 to 15 in. clumps............ $225 \quad 2000 \quad 18000$

15 to 18 in. clumps........... $275 \quad 2500$

maximum - white to blush, late blooming

Great Laurel

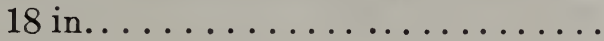

$250 \quad 2200$

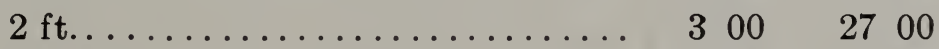

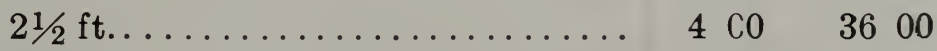

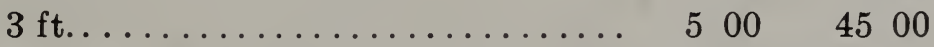

WE HAVE A STOCK OF THIS SPECIES WHICH ARE VERY FINE, EXTRA BUSHY SPECIMENS. THEY WILL MEASURE FROM $2 \frac{1}{2} \mathrm{ft}$. TO $6 \mathrm{ft}$. IN SPREAD. PRICES QUOTED UPON REQUEST. 


\section{Each Per 10 Per 100}

\section{RHODODENDRONS-HARDY HYBRID VARIETIES}

If upon receipt of order we are sold out of the item ordered we shall fill the order with the variety most nearly resembling the desired sort UNLESS OTHERWISE SPECIFIED in the order.

Owing to the scarcity of Hybrid Rhododendrons and to our comparatively low prices in spite of this scarcity we reserve the right to refuse any considerable order for Rhododendrons unless accompanied by an order for a fair amount of other material.

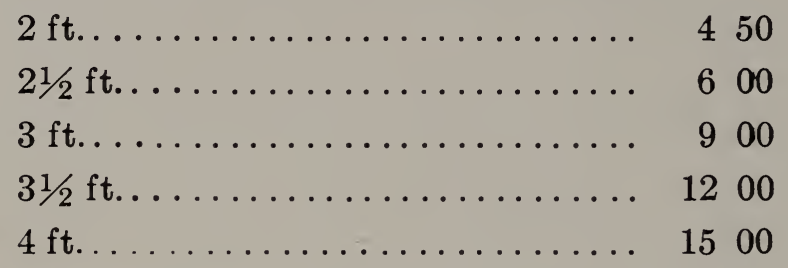

ABRAHAM LINCOLN - Rosy Red $-2 \mathrm{ft}$., $21 / 2 \mathrm{ft}$.

ALBUM ELEGANS - Blush White -- $21 / 2 \mathrm{ft}$., $3 \mathrm{ft}$., $31 / 2 \mathrm{ft}$., $4 \mathrm{ft}$.

ALBUM GRANDIFLORUM - large White $--2 \mathrm{ft}$., $21 / 2 \mathrm{ft}$., $3 \mathrm{ft}$., $31 / 2 \mathrm{ft}$.

ATROSANGUINEUM-Crimson-2 ft.

BOULE-DE NEIGE - Early, white dwarf. This sort is measured by breadth rather than height. 18 in., $2 \mathrm{ft}$., $21 / 2 \mathrm{ft}$., spread.

CARACTACUS - Medium Red $-2 \mathrm{ft}$., $21 / 2 \mathrm{ft}$., $3 \mathrm{ft}$.

CATAWBIENSE GRANDIFLORA - Rosy purple. $-2 \mathrm{ft}$., $21 / 2 \mathrm{ft}$.

CATAWBIENSE GRANDIFLORA ALBA - White; bright yellow spots $-2 \mathrm{ft} ., 2 \frac{1}{2} \mathrm{ft}$.

CHARLES BAGLEY - Crimson $-2 \mathrm{ft} ., 2 \frac{1}{2} \mathrm{ft}$.

CHARLES DICKENS - Bright Crimson; mahogany spots $-2 \mathrm{ft}$., $21 / 2 \mathrm{ft}$.

DELICATISSIMUM - Blush $-2 \mathrm{ft}$., $21 / 2 \mathrm{ft}$.

EDWARD S. RAND - Clear light red $-2 \mathrm{ft}$., $21 / 2 \mathrm{ft}$.

EVERESTIANUM - Rosy Lilac; edges crimped $-2 \mathrm{ft}$., $21 / 2 \mathrm{ft}$.

F. D. GODMAN - Medium Red; dark spots $-21 / 2 \mathrm{ft}$.

GENERAL GRANT - Red $-2 \mathrm{ft} ., 21 / 2 \mathrm{ft}$

H. H. HUNNEWELL - Dark crimson $-2 \mathrm{ft}$.

KETTLEDRUM - Medium red; purple tinge $-2 \mathrm{ft}$., $21 / 2 \mathrm{ft}$.

LADY ARMSTRONG - Deep pink; dark spots $-2 \frac{1}{2} \mathrm{ft}$., $3 \mathrm{ft}$.

LADY GREY EGERTON - Large blush lilac - $2 \frac{1}{2} \mathrm{ft}$., $3 \mathrm{ft}$.

MRS. MILNER - Large bright red $-21 / 2 \mathrm{ft}$.

PARSONS' GLORIOSUM - Blush lilac; yellow spots $-2 \mathrm{ft}$., $2 \frac{1}{2} \mathrm{ft}$., $3 \mathrm{ft}$.

PARSONS' GRANDIFLORUM - Rosy red $-2 \mathrm{ft}$., $2 \frac{1}{2} \mathrm{ft}$.

PRESIDENT LINCOLN - Pale rosy lilac $-31 / 2 \mathrm{ft}$.

ROSEUM ELEGANS - Deep rose; lavender tinge $-2 \mathrm{ft}$., $21 \frac{1}{2} \mathrm{ft}$., $3 \mathrm{ft}$. 


\section{DECIDUOUS SHADE AND ORNAMENTAL TREES}

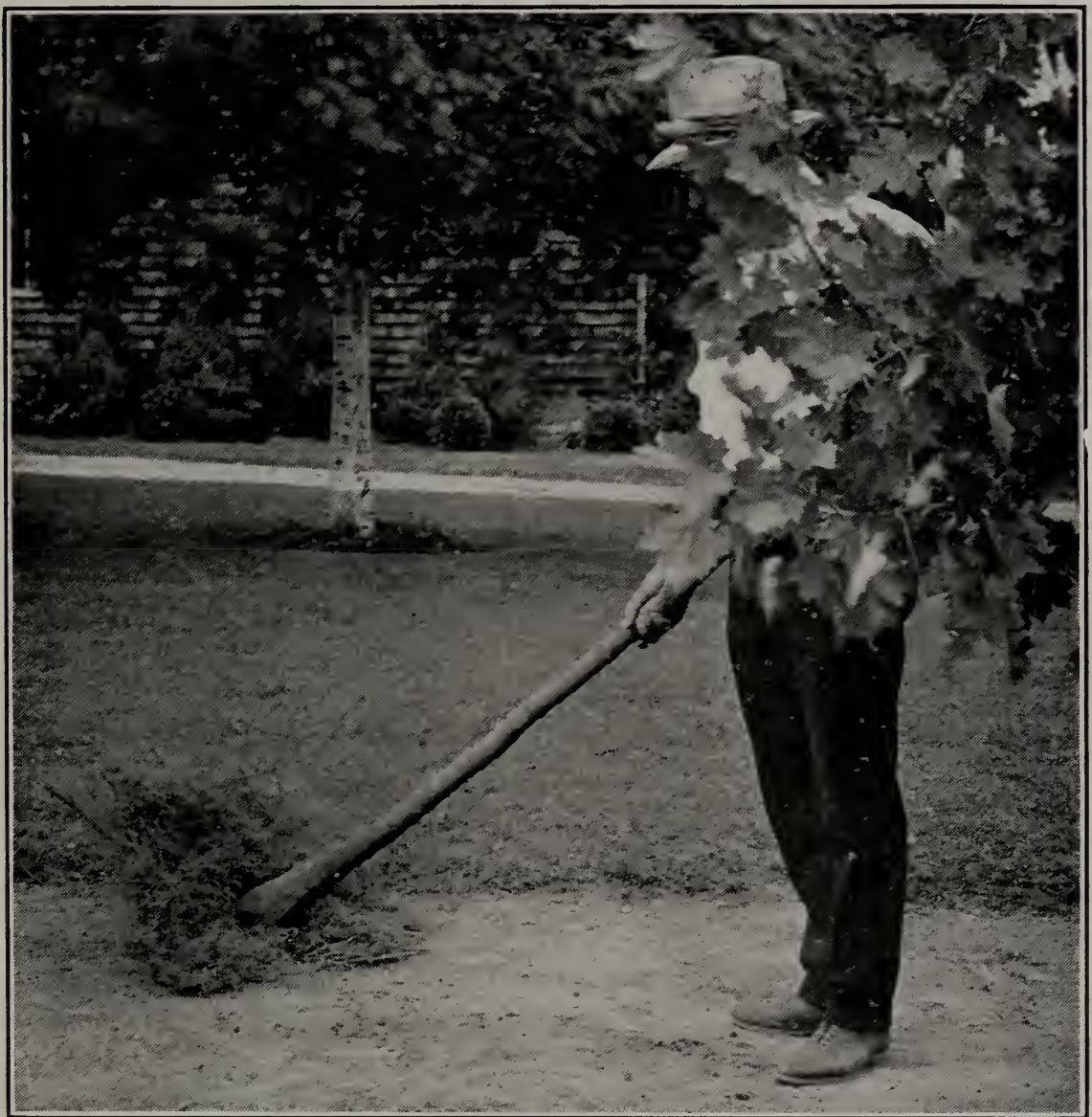

A sample Norway Maple (Acer platancides) 12 feet tall. Note the dense compact mass of roots and the sturdy trunk, particulariy straight for this species. This tree is typical of our Deciduous Trees.

Varieties marked "B \& B" are always dug with Ball \& Burlap at No Additional Cost.

ACANTHOPANAX maximowiczii

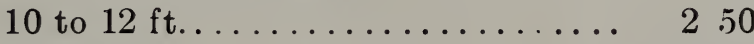

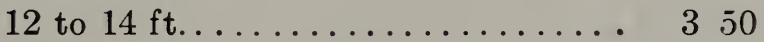

ACER dasycarpum

Silver Maple

12 to $14 \mathrm{ft} .13 / 4$ to 2 in. cal........ $200 \quad 1800$

14 to $16 \mathrm{ft} .2$ to $21 / 2$ in. cal......... $250 \quad 2200 \quad 20000$

16 to $18 \mathrm{ft} .2 \frac{1}{2}$ to $3 \mathrm{in}$. cal....... $400 \quad 350$

Specimens 3 to 4 in. cal......... $700 \quad 6006$ 
ACER-continued

dasy. wieri

12 to $14 \mathrm{ft.} 1 \frac{1}{2}$ to $13 / 4$ in. cal....... 260

14 to $16 \mathrm{ft.} 13 / 4$ to 2 in. cal......... 300

16 to $18 \mathrm{ft} .2$ to $21 / 2$ in. cal........ 400

ginnala

3 to $4 \mathrm{ft} . \ldots \ldots \ldots \ldots \ldots \ldots$

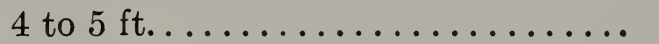

5 to $6 \mathrm{ft} . \ldots \ldots \ldots \ldots \ldots \ldots$

negundo

12 to $14 \mathrm{ft}$.

neg. argentea

8 to $10 \mathrm{ft} . . . \ldots \ldots \ldots \ldots \ldots \ldots$

10 to $12 \mathrm{ft}$.

neg. aurea

8 to $10 \mathrm{ft} . \ldots \ldots \ldots \ldots \ldots \ldots$

10 to $12 \mathrm{ft} . \ldots \ldots \ldots \ldots \ldots \ldots \ldots$

platanoides

10 to $12 \mathrm{ft} .1 \frac{1}{4}$ to $11 / 2$ in. cal.......

12 to $14 \mathrm{ft} .1 \frac{1}{2}$ to $13 / 4$ in. cal .......

12 to $14 \mathrm{ft} .13 / 4$ to 2 in. cal.........

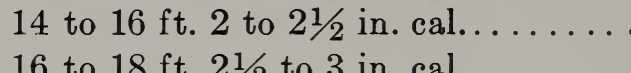

16 to $18 \mathrm{ft} .21 / 2$ to 3 in. cal.........

16 to $18 \mathrm{ft} .3$ to $31 / 2$ in. cal.........

18 to $20 \mathrm{ft} .31 / 2$ to 4 in. cal.........

plat. schwedleri

12 to $14 \mathrm{ft} .1 \frac{1}{2}$ to $1 \frac{3}{4}$ in. cal.......

12 to $14 \mathrm{ft} .13 / 4$ to 2 in. cal. . . . . . .

14 to $16 \mathrm{ft} .2$ to $21 / 2$ in. cal.........

16 to $18 \mathrm{ft} .21 / 2$ to 3 in. cal........ 700

rubrum

6 to $8 \mathrm{ft}$

10 to $12 \mathrm{ft}$.

12 to $14 \mathrm{ft} . \ldots \ldots \ldots \ldots \ldots \ldots \ldots$

14 to $16 \mathrm{ft} . \ldots \ldots \ldots \ldots \ldots \ldots \ldots \ldots$. 400

16 to $18 \mathrm{ft} . \ldots \ldots \ldots \ldots \ldots \ldots \ldots \ldots$

saccharum

12 to $14 \mathrm{ft} .1 \frac{1}{2}$ to $13 / 4$ in. cal. ......

14 to $16 \mathrm{ft} .13 / 4$ to 2 in. cal. . . . . . .

14 to $16 \mathrm{ft} .2$ to $21 / 2$ in. cal . . . . . . .

16 to $18 \mathrm{ft} .21 / 2$ to 3 in. cal.........

16 to $18 \mathrm{ft} .3$ to $3 \frac{1}{2}$ in. cal...........

18 to $24 \mathrm{ft} .31 / 2$ to 4 in. cal.
Siberian Maple

$90 \quad 800$

$100 \quad 900$

$125 \quad 1100$

Ash-leaved Maple

200

Silvery Ash-leaved Maple

$300 \quad 2600$

$400 \quad 3500$

Golden Ash-leaved Maple

$300 \quad 2600$

$400 \quad 3500$

Norway Maple

$200 \quad 1750 \quad 16000$

$205 \quad 2250 \quad 20000$

$\begin{array}{llllll}3 & 00 & 28 & 00 & 260 & 00\end{array}$

$\begin{array}{llllll}4 & 00 & 36 & 00 & 320 & 00\end{array}$

$\begin{array}{llllll}5 & 00 & 45 & 00 & 400 & 00\end{array}$

$800 \quad 7000$

$\begin{array}{llll}15 & 00 & 130 & 00\end{array}$

Purple Norway Maple

400

500

Red Maple

$180 \quad 1600$

250

300

Sugar Maple

$250 \quad 2200 \quad 20000$

$300 \quad 2800 \quad 25000$

$\begin{array}{lllll}400 & 3600 & 32000\end{array}$

$\begin{array}{llllll}6 & 00 & 50 & 00 & 420 & 00\end{array}$

$\begin{array}{llll}10 & 00 \quad 90 & 00\end{array}$ 
AESCULUS hippocastanum

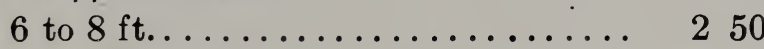

10 to $12 \mathrm{ft} .2$ to $21 / 2$ in. cal........ 400

12 to $14 \mathrm{ft} .21 / 2$ to 3 in. cal......... 500

14 to $16 \mathrm{ft} .3$ to 4 in. cal.......... 1000

Specimens 4 to 5 in. cal. ........ 2000

pavia carnea

8 to $10 \mathrm{ft} . \ldots \ldots \ldots \ldots \ldots \ldots \ldots \ldots . \ldots \ldots$

10 to $12 \mathrm{ft} . \ldots \ldots \ldots \ldots \ldots \ldots \ldots \ldots . \ldots \ldots$

12 to $14 \mathrm{ft} . \ldots \ldots \ldots \ldots \ldots \ldots \ldots . \ldots \ldots$

14 to $16 \mathrm{ft} . \ldots \ldots \ldots \ldots \ldots \ldots \ldots . \ldots . \ldots$

ARALIA spinosa

2 to $3 \mathrm{ft} . \ldots \ldots \ldots \ldots \ldots \ldots \ldots \ldots$

BETULA atba laciniata

6 to $8 \mathrm{ft} . \ldots \ldots \ldots \ldots \ldots \ldots \ldots \ldots . \ldots 175 \quad 1400$

8 to $10 \mathrm{ft} . \ldots \ldots \ldots \ldots \ldots \ldots \ldots \ldots 225 \quad 200$

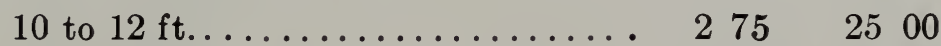

12 to $14 \mathrm{ft} . \ldots \ldots \ldots \ldots \ldots \ldots \ldots \ldots$

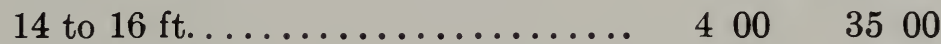

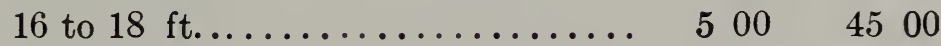

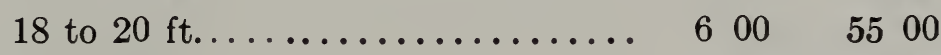

alba pyramidalis

Pyramidal White Birch

14 to $16 \mathrm{ft} \ldots \ldots \ldots \ldots \ldots \ldots \ldots \ldots \ldots, 500 \quad 4500$

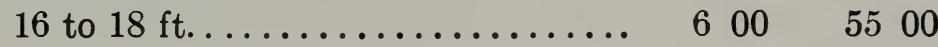

lenta

Black Birch

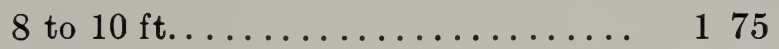

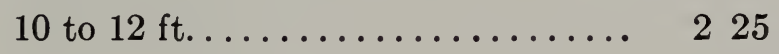

lutea

Yellow Birch

10 to $12 \mathrm{ft} . \ldots \ldots \ldots \ldots \ldots \ldots \ldots . \ldots \ldots$

12 to $14 \mathrm{ft} . \ldots \ldots \ldots \ldots \ldots \ldots \ldots \ldots$

papyracea

\section{Canoe Birch}

8 to $10 \mathrm{ft} . \ldots \ldots \ldots \ldots \ldots \ldots \ldots$

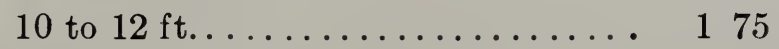

12 to $14 \mathrm{ft} . \ldots \ldots \ldots \ldots \ldots \ldots \ldots \ldots$

CARPINUS americanus

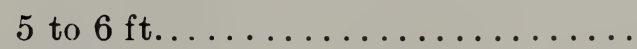

American Hornbeam

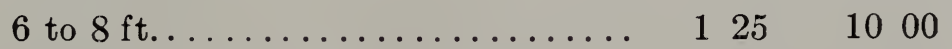

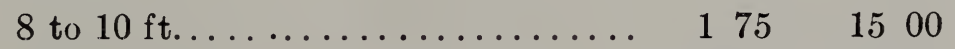

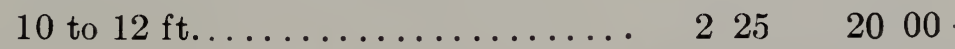

betulus

5 to $6 \mathrm{ft}$. $\mathrm{B} \& \mathrm{~B}$

European Hornbeam

6 to $7 \mathrm{ft} . \mathrm{B} \& \mathrm{~B}$

$100 \quad 800$

$12510^{\circ} 00$

7 to $8 \mathrm{ft} . \mathrm{B} \& \mathrm{~B} \ldots \ldots \ldots \ldots \ldots \ldots \ldots \ldots \ldots$

8 to $10 \mathrm{ft} . \mathrm{B} \& \mathrm{~B} \ldots \ldots \ldots \ldots \ldots \ldots \ldots 225 \quad 2000$

10 to $12 \mathrm{ft} . \mathrm{B} \& \mathrm{~B} \ldots \ldots \ldots \ldots \ldots \ldots \ldots 300 \quad 2700$ 
CATALPA bungei

speciosa

$2 \mathrm{yr}$ heads.

10 to $12 \mathrm{ft}$

12 to $14 \mathrm{ft}$.

14 to $16 \mathrm{ft}$.

CERASUS avium fl. pl. alba

4 to $5 \mathrm{ft}$. B \& B

5 to $6 \mathrm{ft}$. B \& B

6 to $7 \mathrm{ft}$. B \& B

japonica fl. pl. alba

10 to $12 \mathrm{ft}$. B \& B

12 to $14 \mathrm{ft}$. B \& B

jap. hisakura

6 to $8 \mathrm{ft}$. B \& B

8 to $10 \mathrm{ft} . \mathrm{B} \& \mathrm{~B}$

CERCIS canadensis

4 to $5 \mathrm{ft} . . . . .$.

CHIONANTHUS virginica

18 to 24 in.

2 to $3 \mathrm{ft}$

3 to $4 \mathrm{ft}$.

CLADRASTIS tinctoria

6 to $8 \mathrm{ft}$.

8 to $10 \mathrm{ft}$

CORNUS florida

2 to $3 \mathrm{ft}$

3 to $4 \mathrm{ft} . \ldots \ldots \ldots \ldots \ldots \ldots \ldots$

4 to $5 \mathrm{ft} . \ldots \ldots \ldots \ldots \ldots \ldots \ldots$

flor. rubra

3 to $4 \mathrm{ft}$. B \& B

4 to $5 \mathrm{ft}$. B \& B

5 to $6 \mathrm{ft}$. B \& B

CRATAEGUS carrieri

6 to $8 \mathrm{ft}$. B \& B

8 to $10 \mathrm{ft}$. coccinea

4 to $5 \mathrm{ft}$

5 to $6 \mathrm{ft}$

6 to $8 \mathrm{ft}$.

8 to $10 \mathrm{ft}$.

10 to $12 \mathrm{ft}$

cordata

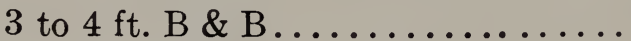

4 to $5 \mathrm{ft}$. B \& B

5 to $6 \mathrm{ft}$. B \&B

6 to $8 \mathrm{ft}$. B \& B

8 to $10 \mathrm{ft} . \mathrm{B} \& \mathrm{~B}$

10 to $12 \mathrm{ft}$. B\&B
Each Per 10 Per 100 Chinese Catalpa

250

Indian Bean

$200 \quad 1800$

$250 \quad 2200$

$300 \quad 2700$

Double White Flowering Cherry 400

500

600

White Japanese Cherry

800

1000

600

\section{Deep Pink Cherry}

800

\section{Red Bud}

$100 \quad 900$

White Fringe

$90 \quad 750$

$125 \quad 1000$

160

Yellow Wood

250

350

White Flowering Dogwood

$\begin{array}{lllll}80 & 700 \quad 6000\end{array}$

$100 \quad 900 \quad 8000$

$150 \quad 1400 \quad 12000$

Pink Florweing Dogwood

$200 \quad 1750$

$\begin{array}{llll}3 & 50 & 32 & 00\end{array}$

500

Carrier's Thorn

200

250

\section{Scarlet Thorn}

$100 \quad 900$

$150 \quad 1250$

$200 \quad 1800 \quad 15000$

$250 \quad 2200 \quad 20000$

$\begin{array}{llll}3 & 00 & 27 & 00\end{array}$

Washington Thorn

$90 \quad 800$

$100 \quad 900$

$150 \quad 1250$

$225 \quad 2000$

$\begin{array}{llll}3 & 00 & 26 & 00\end{array}$

$400 \quad 3500$ 
CRATAEGUS-continued

crus-galli

4 to $5 \mathrm{ft} . \ldots \ldots \ldots \ldots \ldots \ldots \ldots$

5 to $6 \mathrm{ft} . \ldots \ldots \ldots \ldots \ldots \ldots \ldots$

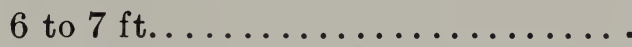

7 to $8 \mathrm{ft}$.

oxyacantha

8 to $9 \mathrm{ft}$. B \&B

9 to $10 \mathrm{ft}$. B \&B

10 to $12 \mathrm{ft} . \mathrm{B} \& \mathrm{~B}$

12 to $14 \mathrm{ft}$. B \&B

oxy. fl. pl. alba

4 to $5 \mathrm{ft}$

5 to $6 \mathrm{ft}$.

10 to $14 \mathrm{ft}$

FAGUS americana

6 to $7 \mathrm{ft}$

7 to $8 \mathrm{ft}$

8 to $10 \mathrm{ft}$

10 to $12 \mathrm{ft}$

sylvatica purpurea pendula

5 to $6 \mathrm{ft}$. B \& B.

6 to $7 \mathrm{ft} . \mathrm{B} \& \mathrm{~B}$

syl. purp. riversi

7 to $8 \mathrm{ft}$. B \&B

8 to $9 \mathrm{ft}$. B \&B

9 to $10 \mathrm{ft}$. B \&B

10 to $11 \mathrm{ft}$. $B \& B$

11 to $12 \mathrm{ft}$. B \&B

FRAXINUS alba

8 to $10 \mathrm{ft}$.

10 to $12 \mathrm{ft}$.

12 to 14

14 to $16 \mathrm{ft}$.

GINKGO biloba

8 to $10 \mathrm{ft}$.

10 to $12 \mathrm{ft} .11 / 4$ to $1 \frac{1}{2}$ in. cal .......
Each Per 10 Per 100

Cockspur. Thorn

$\begin{array}{lllll}90 & 800 & 70 & 00\end{array}$

$125 \quad 1000 \quad 9000$

$150 \quad 1400 \quad 12500$

$200 \quad 1750 \quad 14000$

Common Hawthorn

$\begin{array}{llll}3 & 00 & 28 & 00\end{array}$

$\begin{array}{llll}4 & 00 & 36 & 00\end{array}$

$\begin{array}{llll}5 & 00 & 4500\end{array}$

$\begin{array}{llll}6 & 00 \quad 5400\end{array}$

Double White Hawthorn

$150 \quad 1350 \quad 12000$

$\begin{array}{llllll}2 & 00 & 18 & 00 & 16000\end{array}$

$225 \quad 2000$

800

\section{American Beech}

$\begin{array}{llllll}3 & 00 & 28 & 00 & 250 & 00\end{array}$

$\begin{array}{llllll}4 & 00 & 36 & 00 & 300 & 00\end{array}$

$500 \quad 4500 \quad 36000$

$\begin{array}{lllll}700 & 60 & 00 & 45000\end{array}$

Weeping Purple Beech

700

800

River's Purple Beech

800

1000

1500

1800

2400

American or White Ash

$150 \quad 1400$

$\begin{array}{llll}2 & 00 & 18 & 00\end{array}$

$250 \quad 2200$

$325 \quad 3000$

Maidenhair Tree

$200 \quad 1800$

$250 \quad 2250$

Butternut

3 to $4 \mathrm{ft}$.

$100 \quad 800$

4 to $5 \mathrm{ft}$.

$125 \quad 1100$ 


\section{LABURNUM alpinum}

3 to $4 \mathrm{ft}$.

4 to $5 \mathrm{ft}$.

vulgare

3 to 4 ft....

4 to $5 \mathrm{ft}$.

LARIX europaea

3 to $4 \mathrm{ft}$. B \&B

4 to $5 \mathrm{ft}$. B \& B .

5 to $6 \mathrm{ft}$. B \& B

6 to $8 \mathrm{ft}$. B \& B.

MAGNOLIA soulangeana

3 to $4 \mathrm{ft}$. B \& B

4 to $5 \mathrm{ft}$. B \& B

MALUS floribunda

7 to $8 \mathrm{ft}$. B \&B

8 to $10 \mathrm{ft}$. B \& B

flor. niedwetzkyana

6 to $7 \mathrm{ft}$. B \& B................ 600

8 to $10 \mathrm{ft}$. B \& B.............. 1000

ioensis fl. pl.

Bechtel's Double Flowering Crab

3 to $4 \mathrm{ft}$. B \&B

4 to $5 \mathrm{ft}$. B\&B

5 to $6 \mathrm{ft}$. B \& B

6 to $8 \mathrm{ft}$. B \&B

PHELLODENDRON sachalinense

4 to $5 \mathrm{ft}$.

5 to $6 \mathrm{ft}$.

6 to $7 \mathrm{ft}$.

POPULUS alba

6 to $8 \mathrm{ft}$.

8 to $10 \mathrm{ft}$

alba canescens

10 to $12 \mathrm{ft} . . . . \ldots \ldots \ldots \ldots . . . .200$

16 to $18 \mathrm{ft} . \ldots \ldots \ldots \ldots \ldots \ldots . . .350$

deltoides

10 to $12 \mathrm{ft} . \ldots \ldots \ldots \ldots \ldots \ldots \ldots$

12 to $14 \mathrm{ft}$.
Golden Chain

150

200

European Larch

$80 \quad 700$

$100 \quad 900$

$125 \quad 1100$

160

Soulange's Magnolia

500

700

Flowering Crab

800

1000

Niedwetzky's Crab

$\begin{array}{llll}150 & 1400\end{array}$

$200 \quad 1800$

$250 \quad 2200$

$400 \quad 3600$

Saghalien Cork Tree

$150 \quad 1200 \quad 10000$

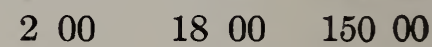

$250 \quad 2200$

White Poplar

120

160

Gray Poplar

Carolina Poplar

175

225 
POPULUS-continucd

fastigiata

8 to $10 \mathrm{ft}$

10 to $12 \mathrm{ft} .11 / 4$ to $11 / 2$ in. cal .......

12 to $14 \mathrm{ft} .1 \frac{1}{2}$ to 2 in. cal. . . . . . . .

14 to $16 \mathrm{ft} .2$ to $2 \frac{1}{2}$ in. cal.........

16 to $20 \mathrm{ft.} 21 / 2$ to $3 \mathrm{in}$. cal.........

PRUNUS pissardi

3 to $4 \mathrm{ft} . \ldots \ldots \ldots \ldots \ldots \ldots$

4 to $5 \mathrm{ft} . \ldots \ldots \ldots \ldots \ldots \ldots \ldots$

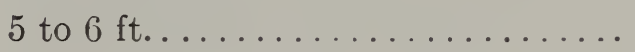

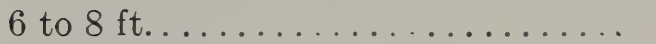

8 to $10 \mathrm{ft} . \ldots \ldots \ldots \ldots \ldots \ldots \ldots$

PTLEA trifoliata

5 to $6 \mathrm{ft} . \ldots \ldots \ldots \ldots \ldots \ldots \ldots$

6 to $8 \mathrm{ft} . \ldots \ldots \ldots \ldots \ldots \ldots \ldots$

8 to $10 \mathrm{ft} . \ldots \ldots \ldots \ldots \ldots \ldots \ldots \ldots . \ldots \ldots$

QUERCUS palustris

10 to $12 \mathrm{ft} .11 / 2$ to $2 \mathrm{in}$. cal. .

12 to $14 \mathrm{ft} .2$ to $21 / 2$ in. cal.

14 to $16 \mathrm{ft} .2 \frac{1}{2}$ to $3 \mathrm{in}$. cal.

16 to $18 \mathrm{ft} .3$ to $4 \mathrm{in}$. cal.

rubra

8 to $10 \mathrm{ft} .1 \frac{1}{4}$ to $1 \frac{1}{2} \mathrm{in}$. cal

10 to $12 \mathrm{ft} .11 / 2$ to 2 in. cal.

12 to $14 \mathrm{ft} .2$ to $21 / 2$ in. cal..........

14 to $16 \mathrm{ft} .21 / 2$ to $3 \mathrm{in}$. cal. .

16 to $20 \mathrm{ft} .3$ to 4 in. cal. .

ROBINIA pseud-acacia

8 to $10 \mathrm{ft}$.

10 to $12 \mathrm{ft}$

SALIX alba

6 to $8 \mathrm{ft}$.

8 to $10 \mathrm{ft}$.

10 to $12 \mathrm{ft}$

babylonica

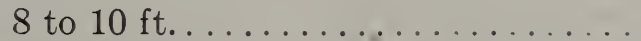

10 to $12 \mathrm{ft}$

pentandra

4 to $5 \mathrm{ft}$.

5 to $6 \mathrm{ft}$.

6 to $8 \mathrm{ft}$.

8 to $10 \mathrm{ft}$

10 to $12 \mathrm{ft}$
Each Per 10 Per 100

Lombardy Poplar

$100 \quad 900$

$\begin{array}{llllll}1 & 50 & 1200 & 9000\end{array}$

$200 \quad 1800 \quad 12000$

$\begin{array}{llllll}2 & 50 & 20 & 00 & 150 & 00\end{array}$

$300 \quad 2500 \quad 20000$

$\begin{array}{llllll}4 & 00 & 32 & 00 & 270 & 00\end{array}$

Purple-leaved Plum

90

120

150

200

250

Hop T'ree

$125 \quad 1000$

$160 \quad 1400$

Pin Oak

$\begin{array}{llll}300 & 2800\end{array}$

$\begin{array}{llll}4 & 00 \quad 36 & 00\end{array}$

c $00 \quad 5500$

$\begin{array}{llll}10 & 00 & 90 & 00\end{array}$

red Oak

250

$300 \quad 2800$

$3 \quad 50 \quad 3200$

$500 \quad 4500$

800

Black Luciisi

200

275

White Willow

$80 \quad 750 \quad 5000$

$100 \quad 850 \quad 6000$

$\begin{array}{llllll}1 & 20 & 10 & 00 & \$ 0 & 00\end{array}$

"Teeping Willow

150

200

Laurel-leaved "illo".

$80 \quad 700 \quad 6000$

$\begin{array}{llllll}100 \quad 850 & 70 & 00\end{array}$

$\begin{array}{llllll}125 & 10 & 00 & 80 & 0\end{array}$

$150 \quad 1250 \quad 10000$

$\begin{array}{lllll}175 & 1500 & 12000\end{array}$ 
SALIX-continued

vitellina aurea

5 to $6 \mathrm{ft}$

6 to $8 \mathrm{ft}$.

vit. aurea pendula

10 to $12 \mathrm{ft}$

12 to $14 \mathrm{ft}$

SOPHORA japonica

5 to $6 \mathrm{ft}$

6 to $7 \mathrm{ft}$

7 to $8 \mathrm{ft}$.

8 to $10 \mathrm{ft}$

SORBUS aucuparia

6 to $8 \mathrm{ft} . \ldots \ldots \ldots \ldots \ldots \ldots$

8 to $10 \mathrm{ft}$.

10 to $12 \mathrm{ft}$.

quercifolia

6 to $8 \mathrm{ft}$

12 to $14 \mathrm{ft}$

SYRINGA japonica

2 to $3 \mathrm{ft}$

3 to $4 \mathrm{ft} . \ldots \ldots \ldots \ldots \ldots \ldots \ldots$

4 to $5 \mathrm{ft}$.

5 to $6 \mathrm{ft}$.

6 to $8 \mathrm{ft}$.

8 to $10 \mathrm{ft}$

TILIA americana

10 to $12 \mathrm{ft.} 1 \frac{1}{2}$ to $2 \mathrm{in.} \mathrm{cal........}$

12 to $14 \mathrm{ft} .2$ to $21 / 2$ in. cal . . . . . . .

14 to $16 \mathrm{ft} .2 \frac{1}{2}$ to 3 in. cal. .......

dasystyla

14 to $16 \mathrm{ft.} 2 \frac{1}{2}$ to 3 in. cal........ $600 \quad 5000$

16 to $18 \mathrm{ft} .3$ to 4 in. cal.......... $1000 \quad 9000$

europaea

10 to $12 \mathrm{ft} .11 / 2$ to 2 in. cal. . . . . . .

12 to $14 \mathrm{ft} .2$ to $2 \frac{1}{2}$ in. cal........

14 to $16 \mathrm{ft} .21 / 2$ to 3 in. cal.........

eur. argentea

14 to $16 \mathrm{ft} .21 / 2$ to 3 in. cal........ 500

16 to $18 \mathrm{ft} .3$ to 4 in. cal.......... 700

$200 \quad 1800$
Each Per 10 Per 100

Golden-barked Willow

$80 \quad 700 \quad 5500$

$100 \quad 850 \quad 7000$

IVeeping Golden-barked IVillow

$\begin{array}{lllll}1 & 25 & 1100 \quad 900\end{array}$

$150 \quad 1350 \quad 11000$

Pagoda Tree

250

325

400

500

European Mountain Ash

$175 \quad 1600$

$250 \quad 2200$

Oak-leaved Mountain Ash

$225 \quad 2000$

500

Japanese Tree Lilac

$80 \quad 700 \quad 6000$

$100 \quad 850 \quad 7000$

$125 \quad 1100 \quad 9000$

$\begin{array}{llllll}1 & 50 & 13 & 00 & 110 & 00\end{array}$

$200 \quad 1500$

$250 \quad 2000$

American Linden

400

500

$700 \quad 6000$

Crimean Linden

European Linden

$300 \quad 2800$

$400 \quad 3600$

$500 \quad 4500$

Silver Linden 
TILIA-continued

eur. parvifolia

Each Per 10 Per 100

8 to $10 \mathrm{ft} . \ldots \ldots \ldots \ldots \ldots \ldots \ldots \ldots 250 \quad 2250$

10 to $12 \mathrm{ft.} 11 / 2$ to 2 in. cal........ $300 \quad 2800 \quad 25000$

12 to $14 \mathrm{ft.} 2$ to $2 \frac{1}{2}$ in. cal........ $400 \quad 3600 \quad 33000$

14 to $16 \mathrm{ft} .21 / 2$ to 3 in. cal........ 600

eur. platyphyllos

12 to $14 \mathrm{ft} .21 / 2$ to 3 in. cal........ $500 \quad 4500$

14 to $16 \mathrm{ft} .3$ to 4 in. cal......... 700

ULMUS americana

American Elm

8 to $10 \mathrm{ft} . \ldots \ldots \ldots \ldots \ldots \ldots \ldots \ldots . \ldots 200 \quad 1500 \quad 13500$

10 to $12 \mathrm{ft} .1 \frac{1}{2}$ to $1 \frac{3}{4}$ in. cal...... $300 \quad 2500 \quad 22000$

12 to $14 \mathrm{ft} .13 / 4$ to 2 in. cal....... $400 \quad 3200$

14 to $16 \mathrm{ft} .2$ to $21 / 2$ in. cal........ $500 \quad 4500$

16 to $18 \mathrm{ft} .21 / 2$ to $3 \mathrm{in.} \mathrm{cal........} 750 \quad 7000$

Specimens 3 to 4 in. cal......... 1000

campestris

English Elm

14 to $16 \mathrm{ft} .2$ to $2 \frac{1}{2}$ in. cal....... 450

16 to $18 \mathrm{ft} .21 / 2$ to 3 in. cal ....... 600

18 to $20 \mathrm{ft} .4$ to $6 \mathrm{in}$. cal..... 1500 to 2500

camp. wheatleyi

Wheatley's Elm

14 to $16 \mathrm{ft} .2$ to $21 / 2$ in. cal........ $500 \quad 4500$

16 to $18 \mathrm{ft} .21 / 2$ to 3 in. cal........ $600 \quad 5500$

montana

10 to $12 \mathrm{ft} .1 \frac{1}{4}$ to $1 \frac{1}{2}$ in. cal .......

10 to $12 \mathrm{ft} .1 \frac{1}{2}$ to $13 / 4$ in. cal .......

12 to $14 \mathrm{ft} .13 / 4$ to 2 in. cal . . . . . . .

14 to $16 \mathrm{ft} .2$ to $2 \frac{1}{2}$ in. cal.........

mont. fastigiata

18 to $20 \mathrm{ft} .21 / 2$ to 3 in. cal........ presthans

18 to $20 \mathrm{ft} .21 / 2$ to 3 in. cal........ 800
Scotch Elm

$200 \quad 1800 \quad 16000$

$\begin{array}{llllll}2 & 75 & 2400 & 210 & 00\end{array}$

$350 \quad 3000$

$450 \quad 4000$

Pyramidal Scotch Elm

$800 \quad 7000$

Fastigiate Elm

\section{BUY TIME}

When you buy nursery stock in the larger sizes you are buying time. Buy big trees and get the benefit of them YOURSELF. The largest trees we list will transplant successfully, because they are grown with heavy root systems. 


\section{DECIDUOUS FLOWERING AND ORNAMENTAL SHRUBS}

Varieties marked "B\&B" are always dug with Ball and Burlap at No Additional Cost.

ACANTHOPANAX pentaphyllum (Aralia)

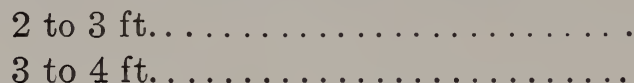
sessiliflorum

4 to $5 \mathrm{ft}$.

5 to $6 \mathrm{ft} . \ldots \ldots \ldots \ldots \ldots \ldots$

AMELANCHIER canadensis (botryapium)

2 to $3 \mathrm{ft} . . . \ldots \ldots \ldots \ldots \ldots . \ldots . \ldots$

3 to $4 \mathrm{ft} . \ldots \ldots \ldots \ldots \ldots \ldots$

4 to $5 \mathrm{ft}$

AMORPHA canescens

18 to 24 in.

2 to $3 \mathrm{ft}$.

ARALIA pentaphylla - see ACANTHOPANAX spinosa - see under Trees

ARONIA arbutifolia

2 to $3 \mathrm{ft} . \ldots \ldots \ldots \ldots \ldots \ldots$

3 to $4 \mathrm{ft} . \ldots \ldots \ldots \ldots \ldots \ldots \ldots$

4 to $5 \mathrm{ft} . \ldots \ldots \ldots \ldots \ldots \ldots \ldots$

5 to $6 \mathrm{ft}$.

melanocarpa (nigra)

2 to $3 \mathrm{ft} . . . \ldots \ldots \ldots \ldots \ldots . \ldots . \ldots$

3 to $4 \mathrm{ft}$.

AZALEA arborescens

15 to 18 in. B \& $\mathrm{B}$

18 to 24 in. $B$ \& $B$

2 to $2 \frac{1}{2} \mathrm{ft}$. B \& B

$21 / 2$ to $3 \mathrm{ft}$. B \&B

calendulacea (lutea)

15 to 18 in. $\mathrm{B} \& \mathrm{~B}$

18 to 24 in. $B$ \& B

2 to $2 \frac{1}{2} \mathrm{ft}$. B \& $\mathrm{B}$

$21 / 2$ to $3 \mathrm{ft}$.

canadensis

12 to 15 in. bushy B \& B.........

15 to 18 in. bushy B \& B
Each Per 10 Per 100

Five-leaved Aralia

$45 \quad 360 \quad 2700$

$50 \quad 420 \quad 3300$

Black-fruited Aralia

$60 \quad 500 \quad 4000$

$70 \quad 600$

Shad Bush

$50 \quad 400 \quad 3000$

$60 \quad 500 \quad 4000$

$\begin{array}{lllll}75 & 600 \quad 4800\end{array}$

Lead Plant

$50 \quad 420$

$60 \quad 500$

Red Chokeberry

$50 \quad 400 \quad 3000$

$55 \quad 450 \quad 3500$

$\begin{array}{lllll}65 & 550 & 4000\end{array}$

$\begin{array}{lllll}75 & 600 & 4500\end{array}$

Black Chokeberry

$50 \quad 4 \quad 50 \quad 3600$

$60 \quad 5 \quad 50$

Fragrant Azalea

$\begin{array}{llllll}1 & 75 & 16 & 00 & 140 & 00\end{array}$

$\begin{array}{llllll}2 & 25 & 20 & 00 & 180 & 00\end{array}$

$260 \quad 2400 \quad 21000$

300

Flame Azalea

$\begin{array}{llllll}2 & 00 & 18 & 00 & 160 & 00\end{array}$

$\begin{array}{llllll}250 & 2200 & 210 & 00\end{array}$

$\begin{array}{llllll}3 & 00 & 27 & 00 & 250 & 00\end{array}$

$400 \quad 3600$

\section{Rhodora}

$150 \quad 1250 \quad 10000$

$\begin{array}{lllll}175 & 1500 & 12000\end{array}$ 
AZALEA-continued

canescens

12 to 15 in. $\mathrm{B} \& \mathrm{~B}$

15 to 18 in. B \&B.

kaempferi

12 to 15 in. $B$ \& $B$

15 to 18 in. $B$ \& $B$

18 to 24 in. $B$ \& B

mollis

12 to 15 in. $B \& B$.

15 to 18 in. $B$ \& B

nudiflora

12 to 15 in. $\mathrm{B} \& \mathrm{~B}$

15 to 18 in. $\mathrm{B} \& \mathrm{~B}$ vaseyii

12 to 15 in. $B$ \& $B$.

15 to 18 in. $B$ \& $B \ldots . . . . . . . .$.

18 to 24 in. B \& B

2 to $2 \frac{1}{2} \mathrm{ft}$. $B$ \& B

viscosa

18 to 24 in. B \& B

2 to $21 / 2 \mathrm{ft}$. $B \& B$

$21 / 2$ to $3 \mathrm{ft}$. $\mathrm{B} \& \mathrm{~B}$

3 to $4 \mathrm{ft}$. B \&B

4 to $5 \mathrm{ft}$. B \&B

\section{BERBERIS ilicifolia}

2 to $21 / 2 \mathrm{ft} . \ldots \ldots \ldots \ldots \ldots \ldots \ldots$

$21 / 2$ to $3 \mathrm{ft} . \ldots \ldots \ldots \ldots \ldots \ldots$

sieboldi

2 to $21 / 2 \mathrm{ft} . \ldots \ldots \ldots \ldots \ldots \ldots$

$21 / 2$ to $3 \mathrm{ft} . \ldots \ldots \ldots \ldots \ldots \ldots \ldots$

3 to $4 \mathrm{ft} . \ldots \ldots \ldots \ldots \ldots \ldots \ldots$

thunbergii

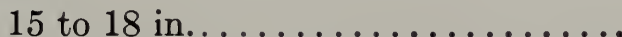

18 to 24 in. bushy ..............

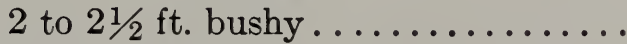

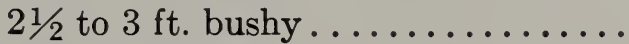

3 to $31 / 2 \mathrm{ft}$. bushy .............

vulgaris

2 to $3 \mathrm{ft} . \ldots \ldots \ldots \ldots \ldots \ldots$

vulg. purpurea

2 to $3 \mathrm{ft} . \ldots \ldots \ldots \ldots \ldots \ldots \ldots$

3 to $4 \mathrm{ft} . \ldots \ldots \ldots \ldots \ldots \ldots$

BUDDLEIA variabilis magnifica

2 yrs.
Each Per 10 Per 100

Gray Azalea

$150 \quad 1400$

$200 \quad 1800$

Japanese Flame Azalea

$\begin{array}{llllll}160 & 1500 & 140 & 00\end{array}$

$200 \quad 1800 \quad 16000$

$250 \quad 2200 \quad 20000$

Japanese Azalea

$\begin{array}{llllll}150 & 1200 & 100 & 00\end{array}$

$175 \quad 1500$

Pinxter Flower

$150 \quad 1400$

$200 \quad 1800$

Southern Azalea-

$\begin{array}{llllll}1 & 75 & 16 & 00 & 140 & 00\end{array}$

$\begin{array}{llllll}2 & 00 & 18 & 00 & 160 & 00\end{array}$

$250 \quad 2200 \quad 20000$

$\begin{array}{llll}3 & 00 & 27 & 00\end{array}$

Swamp Honeysuckle

$\begin{array}{llllll}2 & 00 & 18 & 00 & 150 & 00\end{array}$

$250 \quad 2200 \quad 20000$

$\begin{array}{llllll}3 & 00 & 28 & 00 & 260 & 00\end{array}$

$\begin{array}{llllll}4 & 00 & 36 & 00 & 320 & 00\end{array}$

$\begin{array}{llll}5 & 00 & 4500\end{array}$

Holly-leaved Barberry

$\begin{array}{lllll}70 & 600 & 5000\end{array}$

$90 \quad 800 \quad 7000$

Siebold's Barberry

$360 \quad 2400$

$50 \quad 400 \quad 3000$

$\begin{array}{lllll}60 & 500 & 3600\end{array}$

Japanese Barberry

$40 \quad 300 \quad 2100$

$\begin{array}{lllll}50 & 360 & 28 & 00\end{array}$

$\begin{array}{lllll}60 & 500 & 36 & 00\end{array}$

$\begin{array}{llll}75 & 600 & 4500\end{array}$

$100 \quad 800$

Common Barberry

$50 \quad 400 \quad 3000$

Purple Barberry

$50 \quad 400 \quad 3000$

$60 \quad 500$

Butterfly Bush

$75 \quad 600$ 
Each Per 10 Per 100

CALLICARPA purpurea

18 to 24 in.

CALYCANTHUS floridus

2 to $3 \mathrm{ft} . \ldots \ldots \ldots \ldots \ldots \ldots \ldots$

3 to $4 \mathrm{ft} . \ldots \ldots \ldots \ldots \ldots \ldots \ldots \ldots$

CEPHALANTHUS occidentalis

2 to $3 \mathrm{ft} . . . \ldots \ldots \ldots \ldots \ldots . . . \ldots$

3 to $4 \mathrm{ft} . \ldots \ldots \ldots \ldots \ldots \ldots \ldots$

CHIONANTHUS virginica - see under Trees

CLETHRA alnifolia

2 to $3 \mathrm{ft} . . . \ldots \ldots \ldots \ldots \ldots \ldots$

3 to $4 \mathrm{ft} . \ldots \ldots \ldots \ldots \ldots \ldots \ldots$

COMPTONIA asplenifolia

2 to $3 \mathrm{ft} . \ldots \ldots \ldots \ldots \ldots \ldots$

CORNUS alternifolia

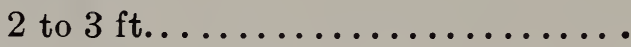

3 to $4 \mathrm{ft} . \ldots \ldots \ldots \ldots \ldots \ldots \ldots \ldots$

baileyi

3 to $4 \mathrm{ft} . \ldots \ldots \ldots \ldots \ldots \ldots \ldots$

4 to $5 \mathrm{ft} . \ldots \ldots \ldots \ldots \ldots \ldots \ldots$

5 to $6 \mathrm{ft} . \ldots \ldots \ldots \ldots \ldots \ldots \ldots$ kousa

2 to $3 \mathrm{ft} . \ldots \ldots \ldots \ldots \ldots \ldots \ldots$

3 to $4 \mathrm{ft} . \ldots \ldots \ldots \ldots \ldots \ldots \ldots$

4 to $5 \mathrm{ft} . \ldots \ldots \ldots \ldots \ldots \ldots \ldots$

mascula

3 to $4 \mathrm{ft} . \ldots \ldots \ldots \ldots \ldots \ldots \ldots \ldots$

4 to $5 \mathrm{ft} . \ldots \ldots \ldots \ldots \ldots \ldots \ldots$

5 to $6 \mathrm{ft} . \ldots \ldots \ldots \ldots \ldots \ldots$

6 to $8 \mathrm{ft} . \ldots \ldots \ldots \ldots \ldots \ldots$

paniculata

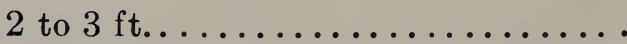

3 to $4 \mathrm{ft} . \ldots \ldots \ldots \ldots \ldots \ldots \ldots$

4 to $5 \mathrm{ft} . \ldots \ldots \ldots \ldots \ldots \ldots \ldots \ldots \ldots$

5 to $6 \mathrm{ft} . \ldots \ldots \ldots \ldots \ldots \ldots \ldots$ sanguinea

2 to $3 \mathrm{ft} . \ldots \ldots \ldots \ldots \ldots \ldots$

3 to $4 \mathrm{ft}$.
Beauty Fruit

$60 \quad 500$

Allspice

$60 \quad 500$

75

Button Bush

$50 \quad 400$

2800

$60 \quad 500$

Sweet Pepper Bush

$60 \quad 500 \quad 3500$

$\begin{array}{lllll}75 & 600 & 4500\end{array}$

Sweet Fern

$75 \quad 60 \mathrm{C}$

Blue Dogwood

$45 \quad 350$

$50 \quad 400$

Bailey's Dogwood

$50 \quad 400 \quad 3000$

$60 \quad 500 \quad 4000$

$\begin{array}{lllll}70 & 600 & 4800\end{array}$

Japanese Flowering Dogwood

$50 \quad 400$

$60 \quad 500$

$75 \quad 600$

Cornelian Cherry

$50 \quad 4 \quad 00 \quad 3000$

$60 \quad 500 \quad 4000$

$\begin{array}{lllll}75 & 600 & 4800\end{array}$

$100 \quad 750$

Gray Dogwood

$350 \quad 2500$

$\begin{array}{lllll}60 & 500 & 3600\end{array}$

$\begin{array}{lllll}75 & 600 & 4800\end{array}$

$100 \quad 800 \quad 6000$

Red Osier

$45 \quad 360$

$50 \quad 400$ 
CORNUS-continued

Each Per 10 Per 100

sericea

Silky Cornel

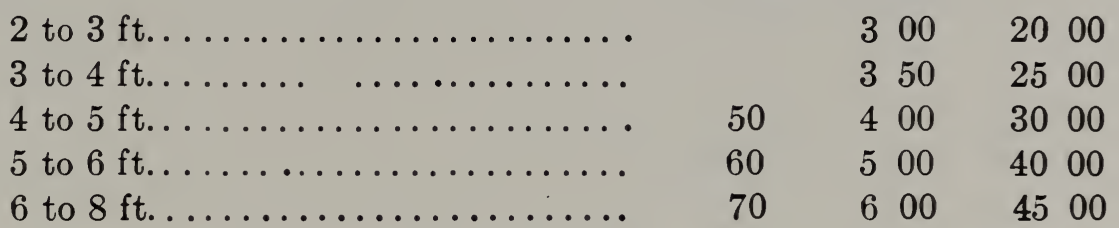

siberica (alba)

Siberian or Red-barked Dogwood

4 to $5 \mathrm{ft} . \ldots \ldots \ldots \ldots \ldots \ldots \ldots \ldots$

$50 \quad 400 \quad 3000$

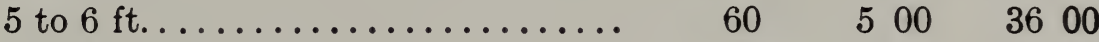

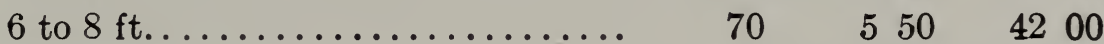

sib. elegantissima

Silver Variegated Dogwood

4 to $5 \mathrm{ft} . . \ldots \ldots \ldots \ldots \ldots \ldots \ldots$

sib. spaethi aurea 75

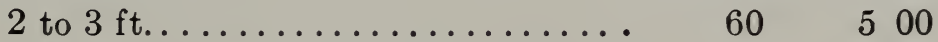

stolonifera lutea (aurea)

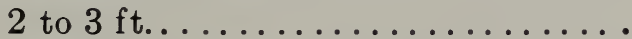

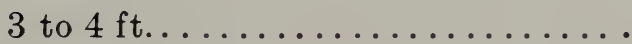

4 to $5 \mathrm{ft} . \ldots \ldots \ldots \ldots \ldots \ldots$

CORYLUS americana

3 to $4 \mathrm{ft} . \ldots \ldots \ldots \ldots \ldots \ldots \ldots \ldots \ldots$

4 to $5 \mathrm{ft}$

Yellow-barked Dogwood

50

400

3300

$\begin{array}{lllll}60 & 5 & 00 & 40 & 00\end{array}$

$\begin{array}{lllll}75 & 6 & 00 & 48 & 00\end{array}$

Hazel Nut

$\begin{array}{llll}50 & 400 & 30 & 00\end{array}$

$60 \quad 500 \quad 4000$

WILSON'S CHINESE COTONEASTERS

Few recent additions to the horticulture of America have met with as much popularity as have the CHINESE COTONEASTERS introduced by Mr. E. H. Wilson, Asst. Director of Arnold Arboretum. These shrubs are all valuable for their profusion of flowers and fruits and some for their glossy, semi-persistent leaves. We take pleasure in offering the following species to those who appreciate new and valuable plants.

COTONEASTER divaricata-Red Flowers and Fruit

15 to 18 in. light............... $60 \quad 500$

foveolata-Red Flowers, Black Fruit

15 to 18 in. light.............. $60 \quad 500$

horizontalis - Red Flowers and Fruit, prostrate Habit

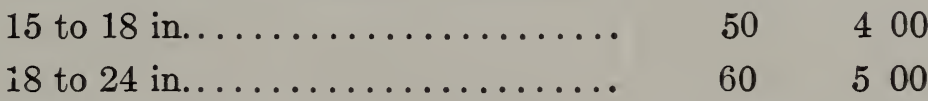

hupehensis-White Flowers, Red Fruit

12 to 15 in. light.............. 60

lucida - Purplish Black Fruit

18 to 24 in. light.............. $60 \quad 500$ 
COTONEASTER-continued

Each Per 10 Per 100

microphylla-Red Flowers and Fruit, Prostrate Habit, Very Small Leaves

12 to 15 in.................... $50 \quad \pm 50$

15 to 18 in..................... $60 \quad 500$

nitens-Red Flowers, Black Fruit

12 to 15 in. light.............. $50 \quad 400$

obscura-Red Flowers and Fruit

18 to 24 in. light............... 60

simonsi-White Flowers, Red Fruit

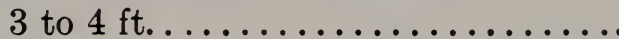

CYDONIA japonica

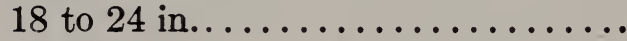

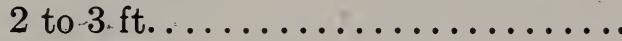

3 to $4 \mathrm{ft} . \ldots \ldots \ldots \ldots \ldots \ldots \ldots$

jap. maulei

18 to 24 in

jap. umbilicata

2 to $3 \mathrm{ft} . \ldots \ldots \ldots \ldots \ldots \ldots \ldots$

3 to $4 \mathrm{ft} . \ldots \ldots \ldots \ldots \ldots . . . . . . .$.

DEUTZIA candidissima

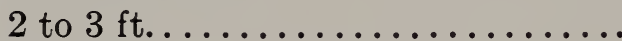

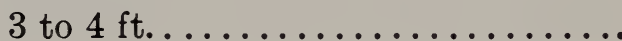

crenata

2 to $3 \mathrm{ft} . . \ldots \ldots \ldots \ldots \ldots \ldots \ldots$

3 to $4 \mathrm{ft} . \ldots \ldots \ldots \ldots \ldots \ldots \ldots$

4 to $5 \mathrm{ft} . \ldots \ldots \ldots \ldots \ldots \ldots$

cren. Pride of Rochester

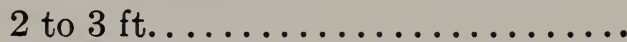

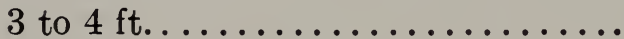

4 to $5 \mathrm{ft} . \ldots \ldots \ldots \ldots \ldots \ldots$

gracilis

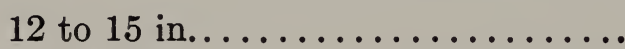

15 to 18 in

$60 \quad 500 \quad 4200$

Japanese Quince

$50 \quad 400 \quad 3500$

$\begin{array}{lllll}60 & 5 & 00 & 45 & 00\end{array}$

$75 \quad 600$

Maule's Japanese Quince

$50 \quad 400$

Red Japanese Quince

$60 \quad 500$

$75 \quad 600$

Double White Deutzia

45. $\quad 360 \quad 2700$

$50 \quad 450$

Single White Deutzia

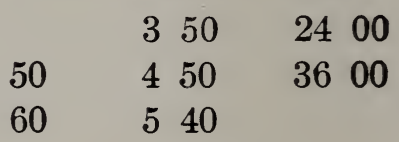

Pink Deutzia

$45 \quad 360$

$50 \quad 450 \quad 3600$

$60 \quad 540$

Dwarf Deutzia

$\begin{array}{llll}4 & 00 & 30 & 00\end{array}$

$\begin{array}{lllll}50 & 450 & 36 & 00\end{array}$

grac. rosea

18 to 24 in

Pink Dwarf Deutzia

$\begin{array}{lllll}60 & 5 & 00 & 36 & 00\end{array}$

Lemoines Deutzia

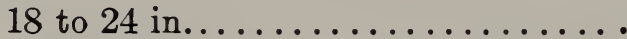

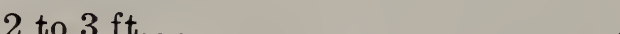

watererii

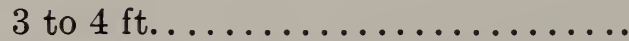

4 to $5 \mathrm{ft} . \ldots \ldots \ldots \ldots \ldots \ldots$

$\begin{array}{lllll} & 3 & 00 & 22 & 00 \\ 50 & 4 & 00 & 28 & 00\end{array}$

Waterer's Deutzia

$50 \quad 4 \quad 50$

$60 \quad 540$ 


\section{DIERVILLA candida}

2 to $3 \mathrm{ft}$.

3 to $4 \mathrm{ft}$.

floribunda

2 to $3 \mathrm{ft}$.

3 to $4 \mathrm{ft}$.

hybrida Eva Rathke

18 to 24 in.

rosea

2 to $3 \mathrm{ft}$

rosea variegata

2 to $3 \mathrm{ft}$.

ELEAGNUS longipes

2 to $3 \mathrm{ft} . . . \ldots \ldots \ldots \ldots \ldots \ldots$

\section{EUONYMUS alata}

2 to $3 \mathrm{ft} . . . \ldots \ldots \ldots \ldots \ldots \ldots$

6 to $8 \mathrm{ft}$. extra bushy Specimens..... bungeana

6 to $8 \mathrm{ft}$. europaez

2 to $3 \mathrm{ft} . \ldots \ldots \ldots \ldots \ldots \ldots$

3 to $4 \mathrm{ft} . \ldots \ldots \ldots \ldots \ldots \ldots \ldots$

4 to $5 \mathrm{ft} . \ldots \ldots \ldots \ldots \ldots \ldots \ldots$ obovata

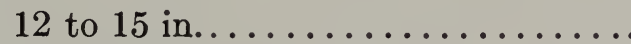
yedoensis

2 to $3 \mathrm{ft} . \ldots \ldots \ldots \ldots \ldots \ldots$

3 to $4 \mathrm{ft} . \ldots \ldots \ldots \ldots \ldots \ldots$

EXOCHORDA grandiflora

18 to 24 in.....................

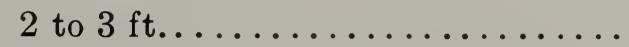

3 to $4 \mathrm{ft} . \ldots \ldots \ldots \ldots \ldots \ldots \ldots$

4 to $5 \mathrm{ft} . \ldots \ldots \ldots \ldots \ldots \ldots$

5 to $6 \mathrm{ft} . \ldots \ldots \ldots \ldots \ldots \ldots$

FORSYTHIA intermedia

2 to $3 \mathrm{ft} . . . \ldots \ldots \ldots \ldots \ldots . . . \ldots$

3 to $4 \mathrm{ft} . \ldots \ldots \ldots \ldots \ldots \ldots \ldots$

4 to $5 \mathrm{ft} . \ldots \ldots \ldots \ldots \ldots \ldots \ldots$

int. spectabilis

4 to $5 \mathrm{ft}$.
Each Per 10 Per 100 White Weigela

$50 \quad 400$

$60 \quad 500$

Red Weigela

$50 \quad 4 \quad 00$

$60 \quad 450$

Carmine Weigela

$50 \quad 450$

Pink Weigela

$50 \quad 400$

Variegated Weigela

$50 \quad 400$

Japanese Oleaster

$50 \quad 450$

Burning Bush

$80 \quad 650$

$450 \quad 4000$

Pink-fruited Spindle Tree

$150 \quad 1200$

Spindle Tree

$50 \quad 450$

$75 \quad 600$

$100 \quad 800$

Prostrate Spindle Tree

$50 \quad 400$

Brilliant Spindle Tree

$60 \quad 500$

$80 \quad 700$

Pearl Bush

$40 \quad 320 \quad 2400$

$50 \quad 4 \quad 00 \quad 3000$

$\begin{array}{lllll}60 & 500 & 40 & 00\end{array}$

$75 \quad 650$

100

\section{Golden Bell}

$40 \quad 360$

$50 \quad 400$

$60 \quad 500$

Large-flowered Golden Bell 75 600 
FORSYTHIA-continued

suspensa

3 to $4 \mathrm{ft} . \ldots \ldots \ldots \ldots \ldots \ldots \ldots$

4 to $5 \mathrm{ft} . \ldots \ldots \ldots \ldots \ldots \ldots \ldots$

5 to $6 \mathrm{ft} . \ldots \ldots \ldots \ldots \ldots \ldots$

susp. fortunei

3 to $4 \mathrm{ft} . \ldots \ldots \ldots \ldots \ldots \ldots$

4 to $5 \mathrm{ft} . \ldots \ldots \ldots \ldots \ldots \ldots \ldots \ldots$

5 to $6 \mathrm{ft} . \ldots \ldots \ldots \ldots \ldots \ldots \ldots$

6 to $8 \mathrm{ft} . \ldots \ldots \ldots \ldots \ldots \ldots$

susp. sieboldi

3 to $4 \mathrm{ft}$.

4 to $5 \mathrm{ft}$

viridissima

2 to $3 \mathrm{ft}$

to $4 \mathrm{ft} . \ldots \ldots \ldots \ldots \ldots \ldots \ldots \ldots$

4 to $5 \mathrm{ft} . \ldots \ldots \ldots \ldots \ldots \ldots$

5 to $6 \mathrm{ft} . \ldots \ldots \ldots \ldots \ldots \ldots$

GENISTA tinctoria

18 t.n 24 in.................

HALESIA carolina

3 to $4 \mathrm{ft} . . . \ldots \ldots \ldots \ldots \ldots . \ldots . \ldots$

HAMMELIS virginiana

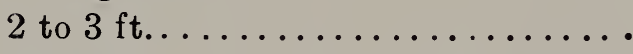

3 to $4 \mathrm{ft} . \ldots \ldots \ldots \ldots \ldots \ldots$.

HIBISCUS syriacus

Double Red, Double ${ }^{\top}$ Pink, Double White, Single White 3 to $4 \mathrm{ft} . \ldots \ldots \ldots \ldots \ldots \ldots \ldots . \ldots \ldots$

HIPPOPHAE rhamnoides

3 to $4 \mathrm{ft} . \ldots \ldots \ldots \ldots \ldots \ldots \ldots$

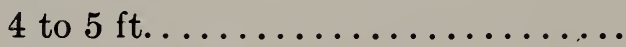

5 to $6 \mathrm{ft}$.

HYDRANGEA arborescens sterilis

2 tc $3 \mathrm{ft} . \ldots \ldots \ldots \ldots \ldots \ldots$

bretschneideri (vestita)

3 to $4 \mathrm{ft}$.

paniculata (type)

2 to $3 \mathrm{ft}$.

paniculata grandiflora

2 to $3 \mathrm{ft}$.

pan. grand. tree form

3 to $4 \mathrm{ft}$.

radiata (nivea)

3 to $4 \mathrm{ft}$.
Each Per 10 Per 100

Drooping Golden Bell

$50 \quad 400 \quad 3000$

$60 \quad 500 \quad 4000$
70

$\begin{array}{llll}70 & 5 & 50 & 4500\end{array}$

Fortune's Golden Bell

$\begin{array}{llll}50 & 400 & 3000\end{array}$

$60 \quad 500 \quad 4000$

$\begin{array}{lllll}70 & 600 & 4500\end{array}$

$80 \quad 650$

Siebold's Golden Bell

$50 \quad 400$

$60 \quad 500$

Green-twigged Golden Bell $40 \quad 350$

$50 \quad 400 \quad 3000$

$60 \quad 500 \quad 4000$

$\begin{array}{lllll}70 & 5 & 50 & 4500\end{array}$

Greenweed

$50 \quad 400$

Silver Bell

$60 \quad 500$

Witch Hazel

$60 \quad 500$

$75 \quad 600$

Rose of Sharon

$60 \quad 500$

Sea Buckthorn

$50 \quad 400$

$60 \quad 500$

$70 \quad 600$

Snowball Hydrangea

$80 \quad 700$

Red-twigged Hydrangea

$75 \quad 600$

Panicled Hydrangea

$60 \quad 500$

Common Hydrangea

$75 \quad 600$

Tree Hydrangea

125

Silvery Hydrangea

$50 \quad 450 \quad 360$ 0n 


\section{HYPERICUM kalmianum}

2 to $3 \mathrm{ft}$.

ILEX verticilata

2 to $3 \mathrm{ft}$

3 to $4 \mathrm{ft} . \ldots \ldots \ldots \ldots \ldots \ldots \ldots \ldots$

4 to $5 \mathrm{ft}$.

5 to $6 \mathrm{ft}$. extra bushy.

6 to $7 \mathrm{ft}$. extra bushy.

KERRIA japonica

18 to 24 in

jap. variegata

18 to 24 in. bushy

2 to $2 \frac{1}{2} \mathrm{ft}$. bushy

LIGUSTRUM amurense

3 to $4 \mathrm{ft} . \ldots \ldots \ldots \ldots \ldots \ldots$

4 to $5 \mathrm{ft}$

ibota

2 to $3 \mathrm{ft}$

iobta regeleanum

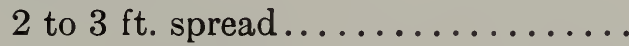

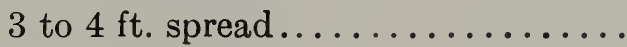

media

2 to $3 \mathrm{ft}$

3 to $4 \mathrm{ft}$.

4 to $5 \mathrm{ft}$.

ovalifolium

2 to $3 \mathrm{ft}$.

3 to $4 \mathrm{ft}$.

vulgare

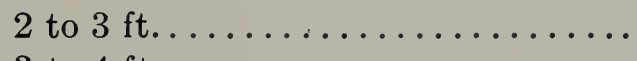

3 to $4 \mathrm{ft}$

LONICERA fragrantissima

2 to $3 \mathrm{ft}$.

morrowii - true spreading form

2 to $3 \mathrm{ft}$.

3 to $4 \mathrm{ft}$

4 to $5 \mathrm{ft}$.

morrowi - upright seedling form

2 to $3 \mathrm{ft} . \ldots \ldots \ldots \ldots \ldots \ldots$

3 to $4 \mathrm{ft} . \ldots \ldots \ldots \ldots \ldots \ldots \ldots$

4 to $5 \mathrm{ft} . \ldots \ldots \ldots \ldots \ldots \ldots \ldots$
Each Per 10 Per 100

St. John's Wort

$60 \quad 500$

Winterberry or Black Alder

$\begin{array}{lllll}60 & 500 & 40 & 00\end{array}$

$\begin{array}{lllll}75 & 6 & 00 & 50 & 00\end{array}$

$\begin{array}{llllll}100 & 850 & 70 & 00\end{array}$

$\begin{array}{llllll}1 & 50 & 12 & 00 & 100 & 00\end{array}$

$\begin{array}{llllll}2 & 00 & 18 & 00 & 150 & 00\end{array}$

Globe Flower

$50 \quad 420$

Variegated Globe Flower

$50 \quad 400 \quad 3000$

$60 \quad 500 \quad 4000$

A moor River Privet

$50 \quad 450$

$60 \quad 500$

Chinese Privet

$50 \quad 400$

Regel's Privet

$\begin{array}{lllll}60 & 450 & 56 & 00\end{array}$

$75 \quad 600$

Japanese Privet

$50 \quad 360 \quad 2800$

$\begin{array}{lllll}60 & 4 & 50 & 36 & 00\end{array}$

$\begin{array}{lllll}70 & 5 & 50 & 40 & 00\end{array}$

California Privet

$\begin{array}{lllll}25 & 180 & 1000\end{array}$

$\begin{array}{llll}30 & 220 & 1200\end{array}$

English Privet

$\begin{array}{lllll}50 & 400 & 28 & 00\end{array}$

$\begin{array}{lllll}60 & 500 \quad 3600\end{array}$

Fragrant Honeysuckle $50 \quad 400$

Japanese Bush Honeysuckle

$50 \quad 400 \quad 3200$

$\begin{array}{lllll}60 & 500 & 40 & 00\end{array}$

$\begin{array}{lllll}70 & 600 & 4800\end{array}$

$40 \quad 300$

$50 \quad 400 \quad 3200$

$60 \quad 500 \quad 4000$ 


\section{LONICERA-continued}

maackii podocarpa

2 to $3 \mathrm{ft}$.

ruprechtiana

3 to $4 \mathrm{ft}$.

4 to $5 \mathrm{ft} . \ldots \ldots \ldots \ldots \ldots \ldots \ldots$

5 to $6 \mathrm{ft} . \ldots \ldots \ldots \ldots \ldots \ldots \ldots$ standishii

3 to $4 \mathrm{ft} . \ldots \ldots \ldots \ldots \ldots \ldots \ldots \ldots$ tatarica

3 to $4 \mathrm{ft} . \ldots \ldots \ldots \ldots \ldots \ldots$.

4 to $5 \mathrm{ft} . \ldots \ldots \ldots \ldots \ldots \ldots \ldots$

5 to $6 \mathrm{ft} . \ldots \ldots \ldots \ldots \ldots \ldots \ldots$ tat. albida

3 to $4 \mathrm{ft} . \ldots \ldots \ldots \ldots \ldots \ldots$

4 to $5 \mathrm{ft} . \ldots \ldots \ldots \ldots \ldots \ldots \ldots$

5 to $6 \mathrm{ft} . \ldots \ldots \ldots \ldots \ldots \ldots$ tat. grandiflora alba

2 to $3 \mathrm{ft} . \ldots \ldots \ldots \ldots \ldots \ldots$

3 to $4 \mathrm{ft} . \ldots \ldots \ldots \ldots \ldots \ldots \ldots$

4 to $5 \mathrm{ft} . \ldots \ldots \ldots \ldots \ldots \ldots \ldots$

5 to $6 \mathrm{ft} . \ldots \ldots \ldots \ldots \ldots \ldots$

tat. grand. rosea

2 to $3 \mathrm{ft} . \ldots \ldots \ldots \ldots \ldots \ldots$

3 to $4 \mathrm{ft} . \ldots \ldots \ldots \ldots \ldots \ldots \ldots$

4 to $5 \mathrm{ft} . \ldots \ldots \ldots \ldots \ldots \ldots \ldots$

5 to $6 \mathrm{ft} . \ldots \ldots \ldots \ldots \ldots \ldots \ldots$

tat. grand. rubra

2 to $3 \mathrm{ft} . \ldots \ldots \ldots \ldots \ldots \ldots$

3 to $4 \mathrm{ft} . \ldots \ldots \ldots \ldots \ldots \ldots$

4 to $5 \mathrm{ft} \ldots \ldots \ldots \ldots \ldots \ldots \ldots$

5 to $6 \mathrm{ft} . \ldots \ldots \ldots \ldots \ldots \ldots \ldots \ldots$

xylosteum

2 to $3 \mathrm{ft} . \ldots \ldots \ldots \ldots \ldots \ldots$

3 to $4 \mathrm{ft} . \ldots \ldots \ldots \ldots \ldots \ldots \ldots$

4 to $5 \mathrm{ft} . \ldots \ldots \ldots \ldots \ldots \ldots \ldots$

MYRICA cerifera

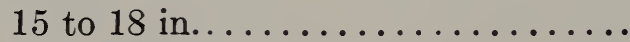

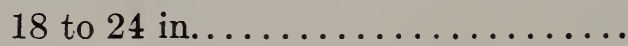

2 to $21 / 2 \mathrm{ft} . \ldots \ldots \ldots \ldots \ldots \ldots \ldots$

$21 / 2$ to $3 \mathrm{ft} . . \ldots \ldots \ldots \ldots \ldots \ldots \ldots$

\section{PHILADEPLHUS coronarius}

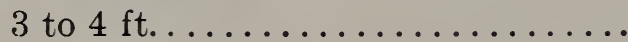

4 to $5 \mathrm{ft} . \ldots \ldots \ldots \ldots \ldots \ldots \ldots \ldots$

5 to $6 \mathrm{ft} . \ldots \ldots \ldots \ldots \ldots \ldots$

6 to $8 \mathrm{ft}$.
Each Per 10 Per 100

Asiatic Honeysucklc 60

Ruprecht's Honeysuckle $50 \quad 400 \quad 3000$ $\begin{array}{lllll}60 & 5 & 00 & 36 & 00\end{array}$ $\begin{array}{llll}75 & 500 \quad 4000\end{array}$

Standish's Honeysuckle $50 \quad 400$

$60 \quad 500$

Tatarian Honeysuckle $50 \quad 450 \quad 3600$ $\begin{array}{lllll}60 & 5 & 00 & 42 & 00\end{array}$ $70 \quad 550 \quad 4800$ Yellow Bush Honeysuckle $40 \quad 320 \quad 2500$ $50 \quad 400 \quad 3000$ $60 \quad 450 \quad 3600$ White Tatarian Honeysuckle $350 \quad 2500$ $\begin{array}{lllll}50 & 400 & 30 & 00\end{array}$ $\begin{array}{lllll}60 & 500 & 3600\end{array}$ $\begin{array}{lllll}70 & 5 & 50 & 4500\end{array}$

Large-flowered Honeysuckle

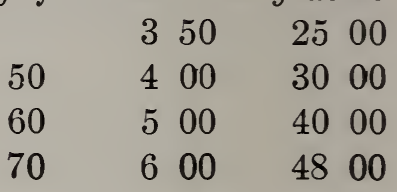

Red Tatarian Honeysuckle

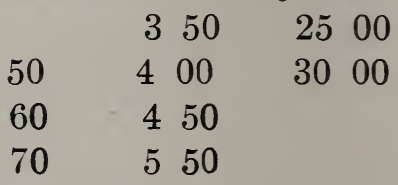

Crimson-fruited Honeysuckle

$50 \quad 400$

60.500

$75 \quad 600$

Candleberry

\begin{tabular}{|c|c|}
\hline & 360 \\
\hline 50 & 400 \\
\hline 30 & 500 \\
\hline & 600 \\
\hline
\end{tabular}

Syringa or Mock Orange $50 \quad 400 \quad 3000$ $60 \quad 500 \quad 3600$ $\begin{array}{lllll}70 & 6 & 00 & 4500\end{array}$ $80 \quad 6 \quad 50 \quad 5000$ 
PHILADELPHUS - continued

cor. aureus

18 to 24 in

cor. nanus

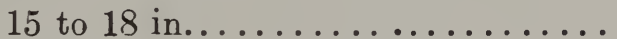

grandiflorus

3 to $4 \mathrm{ft} . \ldots \ldots \ldots \ldots \ldots \ldots$

4 to $5 \mathrm{ft} . \ldots \ldots \ldots \ldots \ldots \ldots \ldots$

5 to $6 \mathrm{ft}$

lemoinei

2 to $3 \mathrm{ft}$.

3 to $4 \mathrm{ft}$.

4 to $5 \mathrm{ft}$.

lemoinei hybrida

AVALANCHE

2 to $3 \mathrm{ft}$.

3 to $4 \mathrm{ft}$

BOUQUE

18 to 24 in.

2 to $3 \mathrm{ft}$. .

CONQUETTE

2 to $3 \mathrm{ft}$.

\section{DAME BLANCHE}

18 to 24 in.

2 to $3 \mathrm{ft}$.

\section{MONT BLANC}

3 to $4 \mathrm{ft} . \ldots \ldots \ldots \ldots \ldots \ldots$

4 to $5 \mathrm{ft}$.

MULTIFLORUS PLENUS

2 to $3 \mathrm{ft} . \ldots \ldots \ldots \ldots \ldots \ldots$

3 to $4 \mathrm{ft}$.

POTEN TILLA fruticosa

18 to 24 in

2 to $3 \mathrm{ft}$.

PRUNUS japonica alba plena

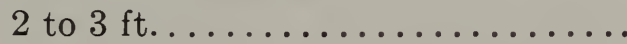

3 to $4 \mathrm{ft}$.

maritima

2 to $3 \mathrm{ft}$.

3 to $4 \mathrm{ft}$.

4 to $5 \mathrm{ft}$.

5 to $6 \mathrm{ft}$

triloba

2 to $3 \mathrm{ft}$.

PYRUS - see ARONIA
Each Per 10 Per 100

Golden Syringa

$70 \quad 650$

Dwarf Mock Orange

$50 \quad 400$

Large-flowered Syringa

$50 \quad 400 \quad 3000$

$\begin{array}{lllll}60 & 5 & 00 & 36 & 00\end{array}$

$\begin{array}{lll}75 & 600 \quad 4500\end{array}$

Lemoine's Mock Orange

$60 \quad 450 \quad 3600$

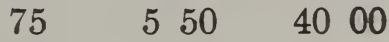

$100 \quad 800$

Lemoine's Hybrid Mock Oranges

$\begin{array}{llll}50 & 400 \quad 3200\end{array}$

$\begin{array}{lllll}60 & 500 \quad 4000\end{array}$

y Fine

$50 \quad 500$

$75 \quad 650$

$\begin{array}{lllll}50 & 4 & 00 & 30 & 00\end{array}$

$45 \quad 350 \quad 2400$

$\begin{array}{llll}50 & 400 \quad 3000\end{array}$

$\begin{array}{llll}60 & 500 \quad 4000\end{array}$

$\begin{array}{lllll}75 & 600 & 5000\end{array}$

$50 \quad 4.00 \quad 3000$

$\begin{array}{lllll}60 & 450 & 3500\end{array}$

Shrubby Cinquefoil

$50 \quad 400 \quad 3000$

$60 \quad 500 \quad 4000$

Double White Almond

60

75

Beach Plum

$50 \quad 400$

$65 \quad 5 \quad 50$

$80 \quad 700$

$100 \quad 850$

Flowering Almond

$75 \quad 600$ 
RHAMNUS caroliniana (frangula)

2 to $3 \mathrm{ft}$. . .

3 to $4 \mathrm{ft} . \ldots \ldots \ldots \ldots \ldots \ldots \ldots \ldots \ldots \ldots \ldots$

4 to $5 \mathrm{ft}$.

catharticus

2 to $3 \mathrm{ft}$.

3 to $4 \mathrm{ft}$

4 to $5 \mathrm{ft}$

RHODORA - see AZALEA canadensis

RHODOTYPUS kerrioides

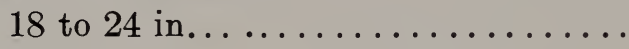

2 to $3 \mathrm{ft} . \ldots \ldots \ldots \ldots \ldots \ldots \ldots \ldots \ldots \ldots$

3 to $4 \mathrm{ft} . \ldots \ldots \ldots \ldots \ldots \ldots \ldots$

RHUS aromatica

2 to $3 \mathrm{ft} . \ldots \ldots \ldots \ldots \ldots \ldots$

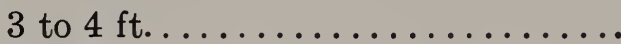

4 to $5 \mathrm{ft} . \ldots \ldots \ldots \ldots \ldots \ldots$

cotinus

2 to $3 \mathrm{ft}$

3 to $4 \mathrm{ft} . \ldots \ldots \ldots \ldots \ldots \ldots \ldots$

4 to $5 \mathrm{ft} . \ldots \ldots \ldots \ldots \ldots \ldots \ldots$

5 to $6 \mathrm{ft} . \ldots \ldots \ldots \ldots \ldots \ldots$ glabra

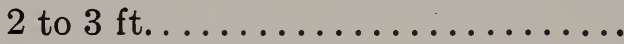

3 to $4 \mathrm{ft} . \ldots \ldots \ldots \ldots \ldots \ldots \ldots \ldots \ldots \ldots$

4 to $5 \mathrm{ft} . \ldots \ldots \ldots \ldots \ldots \ldots . . . . . . .$.

5 to $6 \mathrm{ft} . \ldots \ldots \ldots \ldots \ldots \ldots$ glab. laciniata

3 to $4 \mathrm{ft} . \ldots \ldots \ldots \ldots \ldots \ldots \ldots$ typhina

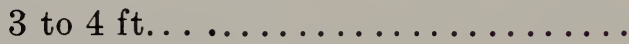

4 to $5 \mathrm{ft} . \ldots \ldots \ldots \ldots \ldots \ldots \ldots \ldots$

6 to $8 \mathrm{ft} . \ldots \ldots \ldots \ldots \ldots \ldots$

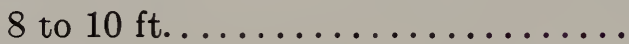

typh. laciniata

2 to $3 \mathrm{ft} . \ldots \ldots \ldots \ldots \ldots \ldots \ldots$

ROSA blanda

carolina

2 to $3 \mathrm{ft} . \ldots \ldots \ldots \ldots \ldots \ldots$

2 to $3 \mathrm{ft} . \ldots \ldots \ldots \ldots \ldots \ldots \ldots \ldots \ldots \ldots \ldots$

3 to $4 \mathrm{ft} . \ldots \ldots \ldots \ldots \ldots \ldots \ldots$

lucida

18 to 24 in multiflora

2 to $3 \mathrm{ft} . \ldots \ldots \ldots \ldots \ldots \ldots \ldots$

3 to $4 \mathrm{ft}$
Each Per 10 Per 100

Carolina Buckthorn

$40 \quad 350$

$\begin{array}{lllll}50 & 4 & 00 & 28 & 00\end{array}$

$60 \quad 450 \quad 3500$ Buckthorn

$40 \quad 320$

$50 \quad 400$

$60 \quad 500$

White Kerria

$40 \quad 320$

2500

$50 \quad 400$

3000

$60 \quad 500$

Fragrant Sumac

$\begin{array}{lllll}50 & 4 & 00 & 27 & 00\end{array}$

$\begin{array}{lllll}60 & 5 & 00 & 36 & 00\end{array}$

$\begin{array}{lllll}65 & 5 & 50 & 42 & 00\end{array}$

Smoke Bush

50

$60 \quad 500$

$75 \quad 600$

100.800

Smooth Sumac

$40 \quad 350 \quad 2800$

$50 \quad 4 \quad 00 \quad 3600$

$\begin{array}{lllll}60 & 5 & 00 & 40 & 00\end{array}$

$75 \quad 600$

Cut-leaved Smooth Sumac

65

Staghorn Sumac

50

$60 \quad 500$

$90 \quad 800$

$150 \quad 1200$

Cut-leaved Staghorn Sumac 60

Meadow Rose

$50 \quad 400$

Swamp Rose

$50 \quad 4 \quad 00 \quad 3000$

$\begin{array}{llll}60 & 500 & 40 & 00\end{array}$

Wild Rose

$50 \quad 400$

Japanese Climbing Rose

$\begin{array}{lllll}50 & 4 & 00 & 27 & 00\end{array}$

$\begin{array}{llll}60 & 500 & 30 & 00\end{array}$ 
ROSA-continued

rubrifolia

2 to $3 \mathrm{ft}$.

3 to $4 \mathrm{ft} . \ldots \ldots \ldots \ldots \ldots . . . . . . . .$.

rugosa

18 to 24 in

rugosa alba

18 to 24 in

setigera

2 to $3 \mathrm{ft}$.

3 to $4 \mathrm{ft} . \ldots \ldots \ldots \ldots \ldots \ldots \ldots$

wichuraiana

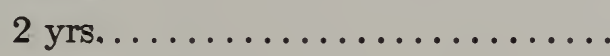

SAMBUCUS canadensis

2 to $3 \mathrm{ft} . . . \ldots \ldots \ldots \ldots \ldots . \ldots . \ldots$

3 to $4 \mathrm{ft}$.

nigra aurea

3 to $4 \mathrm{ft} . \ldots \ldots \ldots \ldots \ldots \ldots$

4 to $5 \mathrm{ft}$.

racemosus (pubens)

2 to $3 \mathrm{ft}$.

3 to $4 \mathrm{ft}$

4 to $5 \mathrm{ft}$

5 to $6 \mathrm{ft}$.

SORBARIA arborea glabrata

2 to $3 \mathrm{ft} . . . \ldots \ldots \ldots \ldots \ldots$

3 to $4 \mathrm{ft} . \ldots \ldots \ldots \ldots \ldots \ldots \ldots$.

4 to $5 \mathrm{ft} . \ldots \ldots \ldots \ldots \ldots \ldots$

SPIRAEA arguta

2 to $3 \mathrm{ft}$. bushy.

3 to $4 \mathrm{ft}$. bushy

4 to $5 \mathrm{ft}$. bushy bumalda

18 to 24 in

2 to $3 \mathrm{ft}$.

bum. Anthony Waterer

18 to 24 in

2 to $3 \mathrm{ft}$

callosa

18 to 24 in opulifolia

4 to $5 \mathrm{ft}$. .

5 to $6 \mathrm{ft} . \ldots \ldots \ldots \ldots \ldots \ldots \ldots$

6 to $8 \mathrm{ft}$.

opul. aurea

2 to $3 \mathrm{ft}$

4 to $5 \mathrm{ft}$.

5 to $6 \mathrm{ft}$
Each Per 10 Per 100

Red-leaved Rose

$50 \quad 400 \quad 3000$

$\begin{array}{lll}60 & 500 \quad 400\end{array}$

Japanese Rose

$60 \quad 500$

White Japanese Rose

$60 \quad 500$

Prairie Rose

350

2700

$50 \quad 400$

3200

Memorial Rose

50

Elderberry

$50 \quad 400$

$60 \quad 500$

Golden Elder

$60 \quad 450$

$75 \quad 600$

Red-berried Elder

$40 \quad 350$

$50 \quad 400$

$60 \quad 500$

$75 \quad 600$

Ash.leaved Spiraea

$50 \quad 400 \quad 3000$

$\begin{array}{lllll}60 & 5 & 00 & 40 & 00\end{array}$

$\begin{array}{llll}75 & 600 & 4800\end{array}$

Hybrid Snow Garland

$50 \quad 450 \quad 3600$

$\begin{array}{lllll}60 & 500 & 40 & 00\end{array}$

$75 \quad 600$

Pink Everblooming Spiraea

$50 \quad 400$

$\begin{array}{lll}60 & 500 & 4000\end{array}$

Crimson Everblooming Spiraea $50 \quad 400 \quad 3300$

$\begin{array}{lllll}60 & 500 & 40 & 00\end{array}$

Fortune's Spiraea

$50 \quad 400$

Nine Bark

$50 \quad 400 \quad 3000$

$\begin{array}{lllll}60 & 5 & 00 & 40 & 00\end{array}$

$70 \quad 550 \quad 4500$

Golden Nine Bark

$40 \quad 320$

$50 \quad 400 \quad 3000$

$\begin{array}{lllll}60 & 500 & 40 & 00\end{array}$ 
SPIRAEA—continued

prunifolia fl. pl.

2 to $3 \mathrm{ft}$

3 to $4 \mathrm{ft} . \ldots \ldots$

4 to $5 \mathrm{ft}$.

reevesi

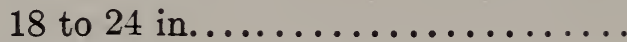

2 to $3 \mathrm{ft}$.

salicifolia

3 to $4 \mathrm{ft}$.

4 to $5 \mathrm{ft} . \ldots \ldots \ldots \ldots \ldots \ldots \ldots$

sorbifolia - see SORBARIA

thunbergii

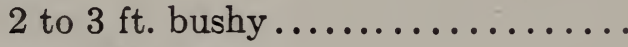

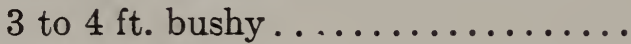

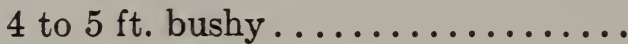
ulmifolia

4 to $5 \mathrm{ft} . . . \ldots \ldots \ldots \ldots \ldots \ldots \ldots$

vanhouttei

2 to $3 \mathrm{ft} . \ldots \ldots \ldots \ldots \ldots \ldots \ldots$

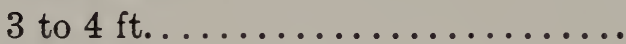

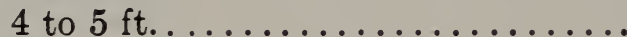

5 to $6 \mathrm{ft}$.

SYMPHORICARPOS racemosus

2 to $3 \mathrm{ft} . . . \ldots \ldots \ldots \ldots \ldots \ldots \ldots$

3 to $4 \mathrm{ft}$.

vulgaris

2 to $3 \mathrm{ft}$

3 to $4 \mathrm{ft}$.

\section{SYRINGA}

josikaea

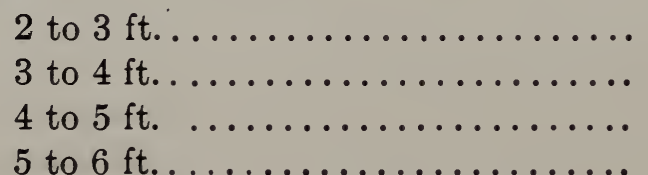

persica

4 to $5 \mathrm{ft} . \ldots \ldots \ldots \ldots \ldots \ldots . . . . .$.

rothomagensis

2 to $3 \mathrm{ft}$

3 to $4 \mathrm{ft}$.

4 to $5 \mathrm{ft}$

5 to $6 \mathrm{ft}$.
Each Per 10 Per 100

Irue Bridal Wreath

50 . 400

$60 \quad 500$

$70 \quad 600$

Reeve's Spiraea

$45 \quad 400$

3200

$50 \quad 450$

Willow-leaved Spiraea

$\begin{array}{lllll}50 & 4 & 00 & 27 & 00\end{array}$

$\begin{array}{lllll}60 & 500 & 36 & 00\end{array}$

Snow Garland

$50 \quad 4.00 \quad 3000$

$\begin{array}{lllll}60 & 5 & 00 & 36 & 00\end{array}$

$\begin{array}{lllll}75 & 600 & 40 & 00\end{array}$

Elm-leaved Spiraea

$60 \quad 500$

Bridal Bower

$\begin{array}{lllll}45 & 4 & 00 & 30 & 00\end{array}$

$50 \quad 4 \quad 50 \quad 3600$

$\begin{array}{lllll}60 & 540 & 45 & 00\end{array}$

$80 \quad 700 \quad 5500$

Snowberry

$50 \quad 400 \quad 3000$

$60 \quad 450 \quad 3600$

Coral Berry

$40 \quad 360 \quad 2400$

$\begin{array}{lllll}50 & 400 & 27 & 00\end{array}$

\section{Hungarian Lilac}

$50 \quad 400$

$60 \quad 500$

$75 \quad 600$

$100 \quad 800$

Persian Lilac

$75 \quad 600$

Rouen Lilac

$60 \quad 500$

$70 \quad 600$

$80 \quad 700$

$100 \quad 856$ 
SYRINGA—continued

villosa

2 to $3 \mathrm{ft}$

3 to $4 \mathrm{ft}$.

4 to $5 \mathrm{ft}$.

5 to $6 \mathrm{ft}$ vulgaris

2 to $3 \mathrm{ft} . \ldots \ldots \ldots \ldots \ldots \ldots \ldots$

3 to $4 \mathrm{ft} . \ldots \ldots \ldots \ldots \ldots \ldots \ldots \ldots$

4 to $5 \mathrm{ft} . \ldots \ldots \ldots \ldots \ldots \ldots \ldots$

vulgaris alba

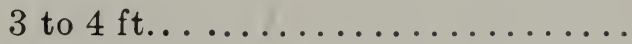

4 to $5 \mathrm{ft} . \ldots \ldots \ldots \ldots \ldots \ldots \ldots$

5 to $6 \mathrm{ft} . \ldots \ldots \ldots \ldots \ldots \ldots \ldots$

6 to $8 \mathrm{ft}$
Each Per 10 Per 100 Himalayan Lilac

$50 \quad 400$

$60 \quad 500$

$75 \quad 600$

$100 \quad 800$

Common Lilac

$60 \quad 500 \quad 3600$

$\begin{array}{lllll}75 & 600 & 4500\end{array}$

$100 \quad 800$

Common White Lilac

60

500

4000

$75 \quad 650 \quad 4800$

$100 \quad 900 \quad 6000$

$125 \quad 1100 \quad 8000$

\section{HYBRID LILACS}

Named Varieties

The varieties in this list are the best sorts we have been able to obtain in either Europe or America. If we have not the size in stock of any variety ordered we shall select the sort most nearly approaching the desired variety UNLESS OTHERWISE SPECIFIED.

\begin{tabular}{|c|c|c|c|}
\hline & Each & Per 10 & Per 100 \\
\hline $2 \mathrm{to} 2 \mathrm{ft}$ & 90 & 800 & 6500 \\
\hline & 125 & 1100 & 9000 \\
\hline t. . & 175 & 1400 & 12000 \\
\hline $\mathrm{ft}$ & 250 & & \\
\hline
\end{tabular}

ABEL CARRIERE - Double. Buds pink, opening bluish lilac. 2 to $3 \mathrm{ft}$., 3 to $4 \mathrm{ft}$.

ALPHONSE LAVELLE - Double. Large pannicles. Pale lavender. 2 to i $3 \mathrm{ft}$., 3 to $4 \mathrm{ft}$.

BELLE DE NANCY - Double. Pink buds open bluish lavender. 2 to $3 \mathrm{ft}$., 3 to $4 \mathrm{ft}$.

BERTHA DAMMANN - Single. White. 2 to $3 \mathrm{ft} ., 3$ to $4 \mathrm{ft}$., 4 to $5 \mathrm{ft}$.

CHARLES BALTET - Single. Bluish pur0le. 2 to $3 \mathrm{ft} ., 3$ to $4 \mathrm{ft}$.

CHARLES JOLY - Double deep red. Extra fine. 2 to $3 \mathrm{ft}$.

CHARLES $X$ - Single. Reddish purple. Very free. 2 to $3 \mathrm{ft}$., 3 to $4 \mathrm{ft}$., 4 to $5 \mathrm{ft}$.

CONDORCET - Double. Large. Pale blue. 2 to $3 \mathrm{ft}$., 3 to $4 \mathrm{ft}$.

CONGO - Single. Deep reddish purple, fading to pinkish purple. 2 to 3 $\mathrm{ft}$., 3 to $4 \mathrm{ft}$.

DOCTOR LINDLEY - Single. Pinkish lilac. 2 to $3 \mathrm{ft}$., 3 to $4 \mathrm{ft}$., 4 to $5 \mathrm{ft}$. DOCTOR MAILLOT - Double. Light lavender, buds opening pale, blue; very free. 2 to $3 \mathrm{ft}$., 3 to $4 \mathrm{ft}$.

DOYEN KETELER - Double. Pale pink lilac. 2 to $3 \mathrm{ft}$., 3 to $4 \mathrm{ft}$. 


\section{HYBRID LILACS-Continued}

JEAN BART - Double. Early. Petals pointed. Bright reddish-purplo bud open pale reddish-purple. 2 to $3 \mathrm{ft}$., 3 to $4 \mathrm{ft}$. JEANNE D'ARC - Double. White. Very free. 2 to $3 \mathrm{ft}$., 3 to $4 \mathrm{ft}$. LEON SIMON - Double. Lavender. 2 to $3 \mathrm{ft}$.

LUDWIG SPAETH - Single. Large. Wine-colored buds open dark red. 2 to $3 \mathrm{ft}$., 3 to $4 \mathrm{ft}$., 4 to $5 \mathrm{ft}$., 5 to $6 \mathrm{ft}$.

MICHAEL BUCHNER - Double. Free. Pink buds open pale bluish lilao.

2 to $3 \mathrm{ft}$., 3 to $4 \mathrm{ft}$.

MME. ABEL CHATENAY - Double. White. 2 to $3 \mathrm{ft}$., 3 to $4 \mathrm{ft}$.

MME. LEMOINE - Double. Large. White. 3 to $4 \mathrm{ft}$., 4 to $5 \mathrm{ft}$., 5 to $6 \mathrm{ft}$. PRESIDENT CARNOT - Double. Long pannicles. Light purple buds open pale blue. 2 to $3 \mathrm{ft}$., 3 to $4 \mathrm{ft}$.

PRINZ NOTGER - Single. Pale Blue. 4 to $5 \mathrm{ft}$., 5 to $6 \mathrm{ft}$.

RUBRA DE MARLEY - Single. Rosy purple. 3 to $4 \mathrm{ft}$., 4 to $5 \mathrm{ft}$., 5 to $6 \mathrm{ft}$. SANGUINEA RUBRA MAJOR - Single. Rosy lilac. 3 to $4 \mathrm{ft}, 4$ to $5 \mathrm{ft}$., 5 to $6 \mathrm{ft}$.

SENATEUR VOLLAND - Double. Free. Bright pink buds open delicate light pinkish-lilac. 2 to $3 \mathrm{fc}$., 3 to $4 \mathrm{ft}$.

WILLIAM ROBINSON - Double. Buds red, opening with outer petals reddish and inner petals bluish. Very fine. 2 to $3 \mathrm{ft}$., 3 to $4 \mathrm{ft}$.

Each Per 10 Per 100

\section{MIXED VARIETIES}

Composed of the above named sorts from which the labels have been lost

\begin{tabular}{|c|c|c|}
\hline $3 \mathrm{ft}$. & 70 & 600 \\
\hline to $4 \mathrm{fu}$. & 90 & 800 \\
\hline$=\mathrm{ft}$ & 125 & 1100 \\
\hline
\end{tabular}

VACCINIUM corymbosum

High-bush Blueberry

18 to 24 in................... $100 \quad 800 \quad 6000$

2 to $3 \mathrm{ft} . \ldots \ldots \ldots \ldots \ldots \ldots . . . .6120 \quad 1000 \quad 8000$

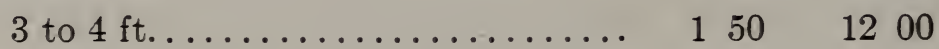

VIBURNUM americanum

American High-bush Cranberry

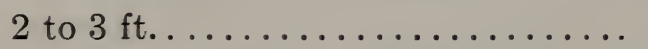

3 to $4 \mathrm{ft}$

4 to $5 \mathrm{ft}$.

5 to $6 \mathrm{ft}$. 
VIBURNUM-continued

cassinoides

2 to $3 \mathrm{ft}$.

3 to $4 \mathrm{ft}$.

4 to $5 \mathrm{ft}$

5 to $6 \mathrm{ft}$.

dentatum

3 to $4 \mathrm{ft} . \ldots \ldots \ldots \ldots \ldots \ldots$

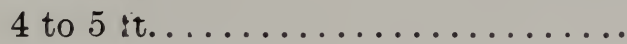

5 to $6 \mathrm{ft}$.

6 to $8 \mathrm{ft}$.

lantana

2 to $3 \mathrm{ft} . \ldots \ldots \ldots \ldots \ldots \ldots$

3 to $4 \mathrm{ft}$.

lentago

2 to $3 \mathrm{ft}$

3 to $4 \mathrm{ft}$.

4 to $5 \mathrm{ft}$. .

5 to $6 \mathrm{ft}$.

6 to $8 \mathrm{ft}$. opulus

2 to $3 \mathrm{ft}$

3 to $4 \mathrm{ft}$.

4 to $5 \mathrm{ft}$.

5 to $6 \mathrm{ft}$.

op. sterilis

4 to $5 \mathrm{ft}$.

tomentosum

2 to $3 \mathrm{ft}$

3 to $4 \mathrm{ft}$.

tom. plicatum

2 to $3 \mathrm{ft}$

3 to $4 \mathrm{ft}$. .

XANTHORRHIZA apiifolia

6 to 12 in. .
Each Per 10 Per 100

Withe Rod

$60 \quad 500$

$70 \quad 600$

$80 \quad 700$

$100 \quad 900$

Arrow-wood

$\begin{array}{lll}60 & 500 \quad 4000\end{array}$

$\begin{array}{lllll}75 & 600 & 5000\end{array}$

$80 \quad 700 \quad 6000$

$\begin{array}{llllll}100 & 8 & 50 & 70 & 00\end{array}$

Wayfaring Tree

$\begin{array}{llll}50 & 400 & 30 & 00\end{array}$

$60 \quad 500$

Sheep Berry

$50 \quad 400 \quad 3000$

$\begin{array}{lllll}60 & 5 & 00 & 40 & 00\end{array}$

$\begin{array}{lllll}75 & 600 & 5000\end{array}$

$100 \quad 800$

$\begin{array}{llll}1 & 50 & 12 & 00\end{array}$

European High-bush Cranberry

$\begin{array}{lllll}40 & 320 & 27 & 00\end{array}$

$50 \quad 400$

$60 \quad 500$

$70 \quad 600$

Common Snowball

$75 \quad 600$

Single Japanese Snowball

$55 \quad 500$

$65 \quad 600$

Japanese Snowball

$75 \quad 600$

$90 \quad 800$

Yellow Root

$\begin{array}{llll}3 & 50 & 27 & 00\end{array}$ 


\section{VINES AND CLIMBERS}

ACTINIDIA arguta

2 yrs. .

3 yrs.

AKEBIA quinata

2 yrs.

AMPELOPSIS quinquefolia

2 yrs.

3 yrs.

quinq. engelmanni

3 yrs.

veitchii

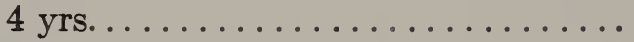

2 yrs.

ARISTOLOCHIA sipho

2 yrs........

BIGNONIA radicans

2 yrs.

3 yrs.

CELASTRUS articulatus

2 yrs.

3 yrs.

4 y

scandens

3 yrs.

4 yrs.

CLEMATIS paniculata

2 yrs..

3 yrs.

virginiana

2 yrs.
Each Per 10 Per 100 Actinidia

75

100

Akebia

$\begin{array}{lll}75 & 6 & 50\end{array}$

Virginia Creeper

$40 \quad 320 \quad 2400$

$50 \quad 400 \quad 3000$

Clinging Virginia Creeper

$50 \quad 400 \quad 3000$

$\begin{array}{lllll}60 & 500 & 36 & 00\end{array}$

Boston Ivy

$40 \quad 320 \quad 2500$

Dutchman's Pipe

$150 \quad 1400$

Trumpet Vine

$\begin{array}{lllll}50 & 400 & 30 & 00\end{array}$

$\begin{array}{lllll}60 & 500 & 36 & 00\end{array}$

Japanese Bittersweet

$40 \quad 330 \quad 2500$

$50 \quad 400 \quad 3000$

$60 \quad 500 \quad 4000$

Roxbury Waxwork

$50 \quad 400$

$60 \quad 500$

Japanese Clematis

$\begin{array}{lllll}50 & 360 & 27 & 00\end{array}$

$\begin{array}{llll}60 & 500 & 40 & 00^{\circ}\end{array}$

American Clematis

$60 \quad 450 \quad 3600$

\section{LARGE FLOWERING GLEMATIS}

Two-year plants $\$ 1.00$ each; $\$ 8.00$ per ten.

DUCHESS OF EDINBURG-Double. White. Fragrant.

HENRYI--Creamy white

JACKMAN II-Large. Velvety purple.

MME. BARON VEILLARD-Unique shade of soft pink

MME. EDWARD ANDRE-Crimson

RAMONA-Light blue.

EUONYMUS radicans-See under Evergreen Shrubs

HEDERA helix

from 4 in. pots.

LONICERA brachypoda halleana

2 yrs.

3 yrs. 
LONICERA-continued

sempervirens

3 yrs.

LYCIUM chinensis

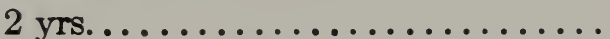

Each Per 10 Per 100 Scarlet Trumpet Honeysuckle $\begin{array}{llll}60 & 5 & 50 & 4500\end{array}$

Matrimony Vine 50

TECOMA-See BIGNONIA

VITIS coignetia

Crimson Glory Vine

2 yrs....................... $50 \quad 400$

5 yrs.................... $100 \quad 800$

heterophylla

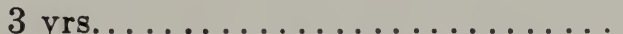

het. amurensis

Japanese Grape

$75 \quad 600$

Manchurian Grape

2 yrs.................... $55 \quad 600 \quad 5000$

WISTARIA chinensis

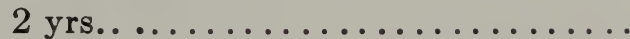

Chinese Blue Wistaria

chin. alba

$75 \quad 650$

$250 \quad 2250$

Chinese White Wistaria

2 yrs.

$75 \quad 650$

10 yrs................... 250

magnifica

American Wistaria

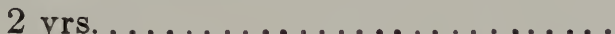

$60 \quad 5 \quad 50 \quad 4500$

\section{QUICK DELIVERY}

In these times of slow transportation quick delivery may be obtained by having your goods shipped by Motor Truck. Long distance trucking of sizable orders is little more expensive than freight, less expensive than express and quicker than express. The goods arrive in better condition for they no not have to be jammed into packing cases. The bother and expense of cartage at the receiving end is also done away with. 


\section{ROSES}

Two-year field-grown plants $\$ 1.00$ each; $\$ 8.50$ per ten.

If we are out of the variety ordered we shall select the variety most nearly approaching the color of the desired sort UNLESS OTHERWISE SPECIFIED.

\section{HYBRID PERPETUAL}

AMERICAN BEAUTY-Crimson.

FISHER HOLMES-Large. Brilliant crimson.

FRAU KARL DRUSCHKI-Large. Pure white.

GEN. JAQUEMINOT-Brilliant crimson.

HARRISON YELLOW-Yellow.

HUGH DICKSON-Brilliant crimson. Fragrant.

LOUIS VAN HOUTTE-Red. Fragrant.

MME. GABRIEL LUIZET-Silvery pink. Fragrant.

M. P. WILDER-Large. Carmine. Fragrant.

MRS. JOHN LAING-Soft pink. Large. Fragrant.

PAUL NEYRON-Deep rose, very large.

PERSIAN YELLOW-Yellow.

PRINCE CAMILLE CE ROHAN-Dark red.

ULRICH BRUNNER-Brilliant cherry red.

\section{HYBRID TEA ROSES}

GEN. MACARTHUR-Large. Sweet. Crimson-scarlet. JUBILEE-Large. Velvety crimson. Fragrant.

KAISERIN AUGUSTA VICTORIA-Cream white. Fragrant.

KILLARNEY_Deep shell-pink.

KILLARNEY WHITE-Pure white, long pointed buds.

MME. CAROLINE TESTOUT-Large. Double. Piak.

MRS. W. C. MILLER-Soft pearly blush, rosy salmon outside.

\section{NEW ROSE INTRODUCTIONS}

The following sorts are the best of the newer roses and will be greatly appreciated by all rose-lovers.

\section{$\$ 1.25$ each; $\$ 11.00$ per ten.}

COLUMBIA-Most pleasing brilliant rose pink, perfect form, fragrant, vigorous and free-blooming.

HADLEY - Deep relvety crimson, does not fade, enormous flowers perfectly formed and sweet-scented.

LOS ANGELES-Luminous flame pink, toned with coral and shaded with gold at base. Long pointed buds open into perfectly formed flowers. Very fragrant.

\section{POLYANTHA ROSES}

\section{$\$ 1.00$ each, $\$ 8.00$ per ten.}




\section{HARDY RAMBLERS}

Two-year field-grown plants 75 cents each; $\$ 6.00$ per ten. CRIMSON RAMBLER WHITE RAMBLER

YELLOW RAMBLER

\section{CLIMBING AND TRAILING ROSES}

Two-year field-grown plants 75 cents each; $\$ 5.00$ per ten. DOROTHY PERKINS-Double. Pink.

DR. VAN FLEET-Flesh pink.

EXCELSA-Double. Red.

HIAWATHA - Single. Crimson; yellow center.

SILVER MOON-Silvery pink; yellow stamens.

TAUSENDSCHON-Large. Pink and white. Fragrant.

WHITE DOROTHY - White

\section{ROSA RUGOSA HYBRIDS}

Two-year field-grown plants' $\$ 1.00$ each; $\$ 9.00$ per ten.

ROSERAIE DE L'HAY-Crimson. 


\section{FRUIT TREES}

APPLES

Each Per 10 Per 100

5 to $7 \mathrm{ft} ., 11-16$ in. and up..........

$\begin{array}{llllll}125 & 1100 \quad 100 & 00\end{array}$

Summer Varieties

Sweet Bough, Williams, Yellow Transparent

Autumn Varieties

Early Harvest, Fameuse

Winter Varieties

Baldwin, McIntosh, Northern Spy, Rhode Island Greening, Wealthy CRAB APPLES

5 to $7 \mathrm{ft} ., 11-16$ in. and up........ 125

Hyslop, Transcendent

CHERRIES

5 to $7 \mathrm{ft}$., 11-16 in. and up........ 150

Early Richmond, Montmorency, Napoleon,

PEACHES

4 to $6 \mathrm{ft} ., 1 / 2$ in. and up.......... $\quad 75 \quad 600$

Carman, Crawford Early, Crawford Late, Elberta, Stump PEARS, STANDARD

5 to $7 \mathrm{ft} ., 11-16$ in. and up......... $150 \quad 1250$

Anjou, Beurre Bosc, Clapp's, Seckel, Sheldon

DWARF PEARS

3 to $5 \mathrm{ft} ., 1 / 2$ in. and up.......... $150 \quad 1250$

Anjou, Bartlett, Clapp's.

PLUMS

5 to $7 \mathrm{ft} ., 11-16$ in. and up......... 150

Abundance, Burbank, Satsuma

QUINCES

$5 / 8$ in. cal.................. $150 \quad 1250$

Orange 
Each Per 10 Per 100

\section{SMALL FRUITS}

GRAPES $2 \mathrm{yrs}$.

Brighton-red

75

600

Brilliant-red

Concord-blue

RASPBERRIES

Campbell's Early-black

Golden Queen, Gregg, St. Regis

\section{INDEX TO BOTANICAL NAMES}

\begin{tabular}{|c|c|c|}
\hline & Page & Page \\
\hline • & 3,4 & Clematis.. . \\
\hline thopanax............ & 21,30 & Clethra.. \\
\hline 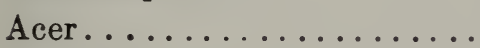 & 21,22 & Comptonia........ \\
\hline dia. & 46 & Cornus.. \\
\hline scuius. & 23 & Corylus.. \\
\hline$\ldots \ldots \ldots \ldots$ & 46 & Cotoneaster.......... 33, \\
\hline Amelanchier............. & 30 & Crataegus........... 24, \\
\hline$\ldots \ldots \ldots \ldots \ldots$ & 30 & Cydonia............... \\
\hline mpelopsis............. & 46 & Daphne................... \\
\hline ndromeda............. & 17 & Deutzia.............. 3 \\
\hline$\ldots \ldots \ldots \ldots \ldots$ & 23,30 & Diervilla................ \\
\hline ylos ........... & 17 & Eleagnus.............. \\
\hline aia.............. & 46 & Euonymus... . . . . . . . . 17, \\
\hline ............. & 30 & Exochorda.............. \\
\hline Azalea................ & . 30,31 & Fagus................ \\
\hline$\ldots \ldots \ldots \ldots \ldots$ & 31 & Forsythia.............. \\
\hline ……..... & 23 & nus............. \\
\hline ............. & 46 & ta................ \\
\hline$\ldots \ldots \ldots \ldots \ldots$ & 31 & Ginkgo.............. \\
\hline$\ldots \ldots \ldots \ldots$ & 17 & . $\ldots \ldots \ldots \ldots \ldots$ \\
\hline ............ & 3 & Hamamelis.............. \\
\hline hus............ & 32 & Hedera................ \\
\hline s.............. & 23 & Hibiscus.............. \\
\hline$\ldots \ldots \ldots \ldots \ldots$ & 24 & Hippophae............. \\
\hline ........ & 32 & Hydrangea........... 36, \\
\hline Cela & 46 & Hypericum ............ \\
\hline anthus........... & 32 & Ilex................. \\
\hline Cerasus. & 24 & Juglans............... \\
\hline Cercis.......... & 24 & Juniperus.......4, 5,6 \\
\hline $\begin{array}{l}\text { Chamaedaphne } \\
\text { Chionanthus... }\end{array}$ & 24 & Kalmia................. \\
\hline $\begin{array}{l}\text { Chionanthus. } \ldots \ldots \ldots \ldots \\
\text { Cladrastis.......... }\end{array}$ & 24 & Kerria............... \\
\hline
\end{tabular}




\begin{tabular}{|c|c|}
\hline Page & Page \\
\hline burnum & Rhus. \\
\hline Carix & Robinia. \\
\hline Leucothoe. & $\ldots 40,41$ \\
\hline Ligustrum. & Roses. \\
\hline Lonicera. . . . . . . . . . 37, 38, 46 & . . 27,28 \\
\hline$\ldots \ldots \ldots \ldots \ldots$ & Sambucus......... \\
\hline$\ldots \ldots \ldots \ldots$ & Sassafras.............. \\
\hline ........ & iadopitys............. \\
\hline$\ldots . .$. & Sophora. \\
\hline 38 & Sorbaria. \\
\hline$\ldots$. & Sorbus. . \\
\hline Phellodendron... & Spiraea...... \\
\hline Philadelphus.......... . 38, 39 & Symphoricarpos.......... \\
\hline Picea............. $8,9,10$ & Syringa......... 28, $42,43,44$ \\
\hline$\ldots$. & Tamarix............... \\
\hline$\ldots 10,11$ & Taxus...... \\
\hline$\ldots 26,27$ & Tecoma.... \\
\hline Potentilla. . & Thuya..... \\
\hline Prunus........ & $\ldots 28,29$ \\
\hline Pseudotsuga... & Tsuga...... \\
\hline Ptlea & Ulmus............... \\
\hline Quercus.. & Vaccinium............. \\
\hline$\ldots 11,12$ & Viburnum............. \\
\hline$\ldots 39,40$ & Vinca...... \\
\hline .. 19,20 & Vitis. \\
\hline hodora. & Wistaria. \\
\hline hodotyp & Xanthorrhiza. \\
\hline
\end{tabular}

\section{INDEX TO COMMON NAMES}

\begin{tabular}{|c|c|c|c|}
\hline & Page & & Page \\
\hline Actinidia. & 46 & Azalea. . & 30,31 \\
\hline Akebia... . & $\ldots$ & Barberry. & 31 \\
\hline Alder. . & $\ldots$ & Beach Plum............ & 39 \\
\hline Allspice. & $\ldots$ & Bearberry.............. & 17 \\
\hline Almond. . & $\ldots$ & Beauty Fruit..... & 32 \\
\hline Andromeda & $\ldots$ & Beech......... & 25 \\
\hline Apple. . & $\ldots$ & Birch..... & 23 \\
\hline Aralia. & 30 & Bittersweet............ & 46 \\
\hline Arborvitae. & $13,14,15$ & Bittersweet, Evergreen..... & 17 \\
\hline Arrowwood & 45 & Blackberry............ & 51 \\
\hline Ash. & 25 & Blueberry............ & 44 \\
\hline Ash, Mount & $\ldots$ & Boxwood... & 17 \\
\hline Asparagus. & 51 & Bridal Bower.... & 42 \\
\hline
\end{tabular}


Page

Bridal Wreath.......... 42

Buckeye............. 23

Buckthorn........... 36, 40

Burning Bush.......... 35

Butterfly Bush......... 31

Butternut............ 25

Button Bush.......... 32

Candleberry............ 38

Catalpa................ 24

Cedar.............. 7,8

Cherry, fruiting........ 50

Cherry, ornamental...... 24, 32

Chokeberry ............ 30

Cinquefoil........... $\quad 39$

Clematis............ 46

Coral Berry.......... 42

Cork Tree............ 26

Cornel............... 33

Cotoneasters, Wilson's

Ch nese.......... 33, 34

Crab, fruiting......... 50

Crab, ornamental........ 26

Cranberry............. 45

Crimson Glory Vine...... 47

Cypress.............. 11, 12

Deutzia............. 34, 35

Dogwood...........24, 32, 33

Dutchman's Pipe........ 40

Elderberry........... 41

Elm............... 29

Fir................ 3,4 ; 11

Garland Flower......... 17

Globe Flower.......... . 37

Golden Bell............ . $\quad 36$

Golden Chain........... $\quad 26$

Grape, ornamental ...... 47

Grapes............... 51

Greenweed............ 36

Hawthorn............ 25

Hazel Nut............. . 33

Hemlock............. 16

Hercules Club.......... 23

Honeysuckle.......31, 37, 38, 46

Hop Tree ........... $\quad 27$

Hornbeam............. 23

Horse Chestnut. . . . . . . . 23
Page

Hydrangea . . . . . . . . 36, 37

Indian Bean........... 24

Ivy............... 46

Juniper $\ldots \ldots \ldots \ldots 4,5,6,7,8$

Kerria............, 40

Larch............... 26

Laurel.............. 18, 19

Lead Plant............ 30

Leather Leaf............ 17

Lilac............28, $42,43,44$

Lily-of-the-Valley Shrub . . . 18

Linden............. 28, 29

Locust.............. 27

Magnolia.............. 26

Maidenhair Tree........ 25

Maple. . ........... 21, 22

Matrimony Vine........ 47

Mock Orange......... 38, 39

Mountan Ash.......... 28

Myrtle............. 18

Nine Bark........... 41

Oak............... 27

Oleaster.............. 35

Osier................ 32

Pagoda Tree........... 28

Partridge Berry ........ 18

Peaches............. 50

Pearl Bush............ 35

Pears.............. 50

Pine............. 10, 11, 12

Pinxter Flower.......... 31

Plum, Beach.......... 39.

Plum, Fruiting......... 50

Plum, Ornamental....... 27

Poplar............. 26, 27

Privet............. 37

Quince, fruiting........ 50

Quince, Ornamental...... 34

Raspberry, Fruiting ...... 51

Red Bud............ 24

Rhododendron......... 19, 20

Rhodora.............. 30

Rhubarb............ 51

Rose...........40, 41, 48, 49

Rose of Sharon.......... 36

Roxbury Waxwork...... 46

Saint John's Wort. ....... 37 


\begin{tabular}{|c|c|}
\hline Page & Paq \\
\hline$\ldots \ldots \ldots$ & Thorn ........... 24, 25 \\
\hline$\ldots \ldots \ldots$ & Thorny Club ........... \\
\hline $\operatorname{erry} \ldots \ldots \ldots \ldots$. & Trumpet Vine........... \\
\hline Bell. ............ & Viburnum............ \\
\hline ush............ & 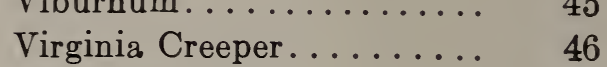 \\
\hline$\ldots \ldots \ldots \ldots \ldots$ & Wayfaring Tree............. \\
\hline Snowberry ............. 42 & Weigela................ \\
\hline $\begin{array}{l}\text { Snow Garland . . . . . . . . } 414,42 \\
\text { Spindle Tree. . . . . . . . }\end{array}$ & \\
\hline 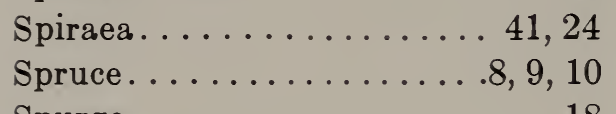 & $\begin{array}{l}\text { Wils on's Chinese Coton- } \\
\text { easters } \ldots \ldots \ldots \ldots \ldots \ldots 33,34\end{array}$ \\
\hline Spur & Winterberry........... \\
\hline Strawberries. & Witch Hazel. . . . . . . . . \\
\hline $\begin{array}{l}\cdots \cdots \cdots \cdots \cdots \\
\mathrm{n} \ldots \ldots \ldots \ldots\end{array}$ & Withe Rod............ \\
\hline Sweet Pepper Bush............ & Wistaria.............. \\
\hline Syringa............ & Yellow Root............ \\
\hline Tamarisk....... & . \\
\hline Tea, New Jersey.. & Yew. \\
\hline
\end{tabular}

\section{Quality Nursery Stock}

Experience has proved that it is unprofitable to plant any but the best grade of Nursery Stock. The cost of transportation, the cost of planting and after care-whether paid in money or in physical effort-are too great to lay out on plants that will fail to fulfill their purpose and which will require that the work be done over in a short while.

At the most, the initial saving in buying poorly grown stock is small-in any case less than the cost of buying new plants and the cost of replanting.

Save yourself time, money and effort. Buy plants that have been grown by experts, on properly selected soil, in a rugged climate. Buy plants that have been properly pruned and trained to give immediate effect. Buy plants that have root systems sufficient to assure transplanting success-buy Framingham Nursery Stock. 


\section{OUR LOCATION}

FRAMINGHAM NURSERIES are located in Framingham, Mass., about 20 miles from Boston and from Worcester, on the main line of the Boston \& Albany division of the New York Central R.R. Also on the New Haven R.R.

Nearly all of the trains to Boston from the West and from New York by the way of Springfield stop here. Trains leave the South Station, Boston, for Framingham every fifteen or twenty minutes.

We are situated about two miles from the Framingham station. We are reached from that point by the Boston-bound cars of the Boston \& Worcester Street Railway Co. Ask the conductor for the FRAMINGHAM NURSERIES STOP. Phone us from the Framingham station and we will meet you there.

From Boston we may also be reached by any focal car of the Boston \& Worcester Street Railway Co. which goes as far as Framingham Junction. These cars leave from Park Square. Ask the conductor for our stop. From Worcester, any Boston-bound local car will leave you at our stop.

By motor from the West, turn from the New York \& Boston Motor Road to the right at East Sudbury and continue for about three miles. From Boston take Commonwealth Ave. to its end, then South St. for about seven miles. You can't help seeing our swinging sign.

Visitors are cordially invited to inspect our nurseries om week days. We are POSITIVELY CLOSED TO BUSINESS ON SUNDAY. 


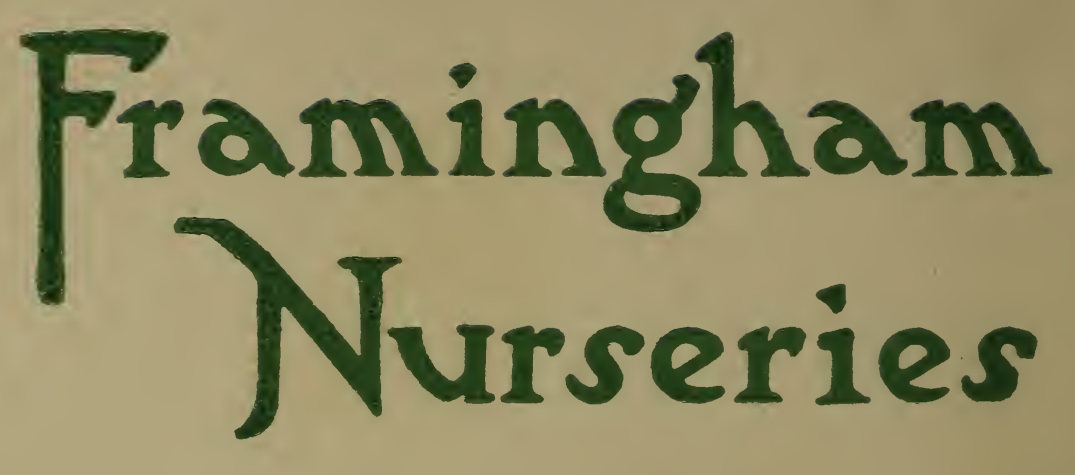

FALL
1921 